\title{
Rapid Oligosaccharide Synthesis Using a Fluorous Protective Group
}

\author{
Tsuyoshi Miura, ${ }^{,+, \S}$ Kohtaro Goto, ${ }^{\dagger}$ Hideki Waragai, ${ }^{\dagger}$ Hiroharu Matsumoto, ${ }^{\dagger}$ \\ Yuriko Hirose, ${ }^{\dagger}$ Masashi Ohmae, ${ }^{\dagger, \oplus}$ Hide-ki Ishida, ${ }^{\dagger}$ Ai Satoh, ${ }^{\dagger}$ and Toshiyuki Inazu ${ }^{*,+, \neq}$ \\ †The Noguchi Institute, 1-8-1 Kaga, Itabashi-ku, Tokyo 173-0003 (Japan), and
}

$\ddagger$ Department of Applied Chemistry, School of Engineering, Tokai University, Kitakaname 1117, Hiratsuka, Kanagawa 259-1292 (Japan)

$\S$ Current address: Faculty of Pharmaceutical Sciences, Chiba Institute of Science, Japan.

If Current address: Department Material Chemistry, Graduate School of Engineering, Kyoto University, Japan.

\section{Supporting Information}

Table of Contents:

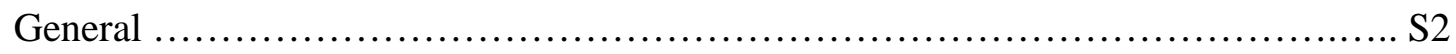

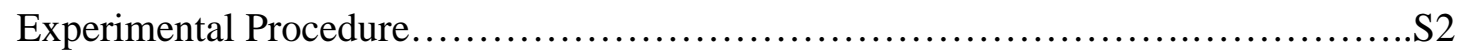

NMR Spectra.......................................................... 13 


\section{Experimental Section}

General. Part of the products was isolated by column chromatography on silica gel. Fluorous solvent FC-72 and Novec HFE-7200 were purchased from 3M Tokyo. Perfluorooctylpropanol was purchased from Daikin.

Compound 3: $\quad \beta$-Alanine ethyl ester hydrochloride (1; $5.65 \mathrm{~g}, 36.8 \mathrm{mmol})$ and $\mathrm{K}_{2} \mathrm{CO}_{3}(17.0 \mathrm{~g}, 123$ mmol) were added to a solution of compound $2^{10}$ (7.59 g, $12.3 \mathrm{mmol}$ ) in dry $\mathrm{CH}_{3} \mathrm{CN}$ (200 mL) at room temperature. After a $17 \mathrm{~h}$ reflux, the reaction mixture was added to water, and then extracted three times with AcOEt. The combined AcOEt layers were washed with $2 \mathrm{M} \mathrm{HCl}$, saturated aqueous $\mathrm{NaHCO}_{3}$, and brine. The organic layers were dried over anhydrous $\mathrm{Na}_{2} \mathrm{SO}_{4}$, and evaporated. The almost pure 3 (5.89 g, 83 \%) thus obtained was used in the next step without further purification. The authentic sample was obtained as a colorless oil by purifying part of the sample (silica gel column chromatography; AcOEt). ${ }^{1} \mathrm{H}$ NMR (400 MHz, $\mathrm{CDCl}_{3}$ ): $\delta=1.27$ (t, $J=7.3 \mathrm{~Hz}, 3 \mathrm{H}$ ), 1.47 (brs, $1 \mathrm{H}$ ), $1.77(\mathrm{~m}, 2 \mathrm{H}), 2.16(\mathrm{~m}, 2 \mathrm{H}), 2.50(\mathrm{t}, J=6.3 \mathrm{~Hz}, 2 \mathrm{H}), 2.70(\mathrm{t}, J=6.8 \mathrm{~Hz}, 2 \mathrm{H}), 2.88(\mathrm{t}, J=6.3 \mathrm{~Hz}, 2 \mathrm{H})$, 4.15 (q, $J=7.3 \mathrm{~Hz}, 2 \mathrm{H})$. HRMS (FAB): Calcd for $\mathrm{C}_{16} \mathrm{H}_{17} \mathrm{~F}_{17} \mathrm{NO}_{2}\left(\mathrm{M}+\mathrm{H}^{+}\right)$: 578.0988, Found: 578.0976.

Compound 4: Jone's reagent ${ }^{21}(1.93 \mathrm{M}, 21.6 \mathrm{~mL})$ was added to a solution of perfluorooctylpropanol $(10.0 \mathrm{~g}, 20.9 \mathrm{mmol})$ in acetone $(200 \mathrm{~mL})$ at $0^{\circ} \mathrm{C}$. After stirring for $4 \mathrm{~h}$ at $0^{\circ} \mathrm{C}$, the reaction mixture was added to cool water. The reaction mixture was extracted three times with AcOEt. The combined AcOEt layers were washed with brine, dried over anhydrous $\mathrm{Na}_{2} \mathrm{SO}_{4}$, and evaporated. The residue was partitioned between toluene and FC-72 $(\times 3)$. The combined FC-72 layers were evaporated to give compound $\mathbf{4}^{11}$ (9.67 g, $\left.94 \%\right)$.

Compound 5a: Triethylamine (4.27 ml, $30.6 \mathrm{mmol})$ and benzotriazol-1yloxytripyrrolidinophosphonium hexafluorophosphate (PyBOP; $6.37 \mathrm{~g}, 12.2 \mathrm{mmol}$ ) were added to a solution of compound 3 (5.89 g, $10.2 \mathrm{mmol})$ and $4(5.27 \mathrm{~g}, 10.7 \mathrm{mmol})$ in dry $\mathrm{CH}_{2} \mathrm{Cl}_{2}(160 \mathrm{~mL})$ at room temperature. After stirring for $3 \mathrm{~h}$ at room temperature, $5 \%$ aqueous citric acid was added to the reaction mixture. The reaction mixture was extracted three times with AcOEt. The combined AcOEt layers were washed with brine, dried over anhydrous $\mathrm{Na}_{2} \mathrm{SO}_{4}$, and evaporated. The crude product was purified by column chromatography on silica gel (hexane-AcOEt, 3:1) to give compound $5 \mathbf{a}$ (9.98 g, 93\%) as a white amorphous solid. ${ }^{1} \mathrm{H}$ NMR (400 MHz, $\left.\mathrm{CDCl}_{3}\right): \delta=1.27(\mathrm{~m}, 3 \mathrm{H}), 1.87(\mathrm{~m}, 2 \mathrm{H}), 2.10$ (m, 2H), $2.61(\mathrm{~m}, 6 \mathrm{H}), 3.45(\mathrm{~m}, 2 \mathrm{H}), 3.64(\mathrm{~m}, 2 \mathrm{H}), 4.16(\mathrm{~m}, 2 \mathrm{H}) ;$ MALDI-TOF-MS: Calcd for $\mathrm{C}_{27} \mathrm{H}_{20} \mathrm{~F}_{34} \mathrm{NO}_{3}\left(\mathrm{M}+\mathrm{H}^{+}\right)$: 1052.1, Found: 1051.1.

Compound 6: A sodium hydroxide aqueous solution $(1 \mathrm{M}, 80 \mathrm{~mL})$ was added to a solution of compound $5 \mathbf{a}$ (9.98 g, $9.49 \mathrm{mmol})$ in 1,4-dioxane $(160 \mathrm{~mL})$ at room temperature. After stirring for $4 \mathrm{~h}$ at $70{ }^{\circ} \mathrm{C}, 2 \mathrm{M} \mathrm{HCl}$ was added, and the reaction mixture was adjusted to $\mathrm{pH}$. The reaction mixture was 
extracted three times with AcOEt. The combined AcOEt layers were washed with brine, dried over anhydrous $\mathrm{Na}_{2} \mathrm{SO}_{4}$, and evaporated. The obtained cmpound 6 (9.52 g, 98 \%) was used in the next step without further purification. The authentic sample was obtained as white needle crystals by purifying part of the sample (recrystalization from AcOEt). m.p. $=126-127^{\circ} \mathrm{C} .{ }^{1} \mathrm{H}$ NMR $\left(400 \mathrm{MHz}, \mathrm{CDCl}_{3}-\right.$ $\left.\mathrm{CD}_{3} \mathrm{OD}=5: 3\right): \delta=1.92(\mathrm{~m}, 2 \mathrm{H}), 2.15(\mathrm{~m}, 2 \mathrm{H}), 2.65(\mathrm{~m}, 6 \mathrm{H}), 3.49(\mathrm{~m}, 2 \mathrm{H}), 3.66(\mathrm{~m}, 2 \mathrm{H})$; MALDITOF-MS: Calcd for $\mathrm{C}_{25} \mathrm{H}_{16} \mathrm{~F}_{34} \mathrm{NO}_{3}\left(\mathrm{M}+\mathrm{H}^{+}\right)$: 1024.1, Found: 1024.6; Calcd for $\mathrm{C}_{25} \mathrm{H}_{15} \mathrm{~F}_{34} \mathrm{NO}_{3} \mathrm{Na}$ $\left(\mathrm{M}+\mathrm{Na}^{+}\right)$: 1046.1, Found: 1046.5.

Compound 8: 4-(Dimethylamino)pyridine (DMAP, $1.71 \mathrm{~g}, 14.0 \mathrm{mmol}$ ) and $N, N^{\prime}-$ dicyclohexylcarbodiimide (DCC, $4.33 \mathrm{~g}, 21.0 \mathrm{mmol}$ ) were added to a solution of compound $7^{13}$ (1.53 g, $3.51 \mathrm{mmol})$ and 6 (11.1 g, $10.8 \mathrm{mmol})$ in dry $\mathrm{CH}_{2} \mathrm{Cl}_{2}(75 \mathrm{~mL})$. After stirring for $20 \mathrm{~h}$ at room temperature, toluene was added to the reaction mixture. The reaction mixture was extracted three times with FC-72. The combined FC-72 layers were evaporated to give the fluorous compound 8 (10.6 g). The fluorous compound 8 was used in the next step without further purification. The authentic sample was obtained as a white amorphous solid by purifying part of the sample (silica gel column chromatography; hexane-AcOEt, 5:2). $\mathrm{R}_{\mathrm{f}}=0.53$ (Hexane : AcOEt $\left.=2: 1\right) ;[\alpha]^{27}{ }_{\mathrm{D}}=3.9^{\circ}(\mathrm{c}=$ 1.03 in FC-72); ${ }^{1} \mathrm{H}$ NMR (400 MHz, $\left.\mathrm{CDCl}_{3}\right): \delta=1.83(\mathrm{~m}, 6 \mathrm{H}), 2.05(\mathrm{~m}, 6 \mathrm{H}), 2.31-2.78$ (m, 18H), 3.16 (m, 2H), 3.24-3.42 (m, 8H), 3.46 (s, 3H), 3.66 (m, 4H), 3.91 (m, 1H), 4.77 (m, 1H), 5.30 (m, 3H), $7.26(\mathrm{~m}, 9 \mathrm{H}), 7.43(\mathrm{~m}, 6 \mathrm{H}) ; \quad$ MALDI-TOF-MS: Calcd for $\mathrm{C}_{101} \mathrm{H}_{67} \mathrm{~F}_{102} \mathrm{~N}_{3} \mathrm{O}_{12} \mathrm{Na}\left(\mathrm{M}+\mathrm{Na}^{+}\right)$: 3474.3, Found: 3476.8.

Compound 9: (+)-Camphorsulfonic acid (CSA, $7.14 \mathrm{~g}, 30.7 \mathrm{mmol}$ ) was added to a solution of compound 8 (10.6 g) in $\mathrm{CHCl}_{3}(150 \mathrm{~mL})-\mathrm{MeOH}(75 \mathrm{~mL})$. After stirring for $3 \mathrm{~h}$ at room temperature, toluene was added to the reaction mixture. The reaction mixture was extracted three times with FC-72. The combined FC-72 layers were evaporated to give the fluorous compound 9 (9.87 g). The fluorous compound 9 was used in the next step without further purification. The authentic sample was obtained as a colorless oil by purifying part of the sample (silica gel column chromatography; Hexane-AcOEt, $1: 2) . \mathrm{R}_{\mathrm{f}}=0.43($ Hexane : AcOEt $=1: 2) ;[\alpha]^{28}=2.8^{\circ}\left(\mathrm{c}=1.01\right.$ in FC-72); ${ }^{1} \mathrm{H}$ NMR $(400 \mathrm{MHz}$, $\left.\mathrm{CDCl}_{3}\right): \delta=1.87$ (m, 6H), 2.05 (m, 6H), 2.47-2.73 (m, 18H), 3.40 (s, 3H), $3.42(\mathrm{~m}, 8 \mathrm{H}), 3.67(\mathrm{~m}, 8 \mathrm{H})$, $4.72(\mathrm{~m}, 1 \mathrm{H}), 5.30$ (m, 3H); MALDI-TOF-MS: Calcd for $\mathrm{C}_{82} \mathrm{H}_{53} \mathrm{~F}_{102} \mathrm{~N}_{3} \mathrm{O}_{12} \mathrm{Na}\left(\mathrm{M}+\mathrm{Na}^{+}\right)$: 3232.2, Found: 3230.9; Calcd for $\mathrm{C}_{82} \mathrm{H}_{53} \mathrm{~F}_{102} \mathrm{~N}_{3} \mathrm{O}_{12} \mathrm{~K}\left(\mathrm{M}+\mathrm{K}^{+}\right)$: 3248.2, Found: 3247.0.

Compound 11: $\quad$ Molecular sieves 4A powder (7.0 g) was added to a solution of compound 9 (1.35 g) and 10 (1.05 g, $2.11 \mathrm{mmol})$ in dry ether (56 mL)-dry $\mathrm{EtOC}_{4} \mathrm{~F}_{9}(14 \mathrm{~mL})$ under an argon atmosphere. After stirring for $2 \mathrm{~h}$ at $0{ }^{\circ} \mathrm{C}$, TMS-OTf $(230 \mu \mathrm{L}, 1.27 \mathrm{mmol})$ was added to the reaction mixture at $0{ }^{\circ} \mathrm{C}$. After stirring for $30 \mathrm{~min}$ at $0{ }^{\circ} \mathrm{C}$, triethylamine $(0.21 \mathrm{~mL})$ was added to the reaction mixture. The 
reaction mixture was filtered on Celite, and washed with AcOEt. The filtrate was then evaporated. The residue was partitioned between $\mathrm{MeOH}$ and FC-72 $(\times 3)$. The combined FC-72 layers were evaporated to give the fluorous compound 11 (1.50 g). The fluorous compound 11 was used in the next step without further purification. The authentic sample was obtained as a white amorphous solid by purifying part of the sample (silica gel column chromatography; Hexane-AcOEt, $1: 1$ ). $\mathrm{R}_{\mathrm{f}}=0.48$ (Hexane : AcOEt $=1: 1) ;[\alpha]^{28}=1.7^{0}\left(\mathrm{c}=1.01\right.$ in FC-72); ${ }^{1} \mathrm{H}$ NMR $\left(400 \mathrm{MHz}, \mathrm{CDCl}_{3}\right): \delta=1.88(\mathrm{~m}$, 6H), 1.97 (s, 3H), 2.04 (s, 3H), 2.06 (s, 3H), 2.10 (m, 6H), 2.13 (s, 3H), 2.56 (m, 18H), 3.41 (s, 3H), 3.44 (m, 6H), 3.64 (m, 7H), 3.92 (m, 3H), 4.09 (m, 1H), 4.20 (m, 1H), 4.45 (m, 1H), 4.74 (m, 1H), 5.05 (m, 1H), $5.22(\mathrm{~m}, 4 \mathrm{H}), 5.41(\mathrm{~m}, 1 \mathrm{H}) ;$ MALDI-TOF-MS: Calcd for $\mathrm{C}_{96} \mathrm{H}_{71} \mathrm{~F}_{102} \mathrm{~N}_{3} \mathrm{O}_{21} \mathrm{Na}\left(\mathrm{M}^{2} \mathrm{Na}^{+}\right)$: 3562.2, Found: 3561.1; Calcd for $\mathrm{C}_{96} \mathrm{H}_{71} \mathrm{~F}_{102} \mathrm{~N}_{3} \mathrm{O}_{21} \mathrm{~K}\left(\mathrm{M}+\mathrm{K}^{+}\right)$: 3578.4, Found: 3577.2.

Compound 12: A solution of sodium methoxide in methanol (28\%, one drop) was added to a solution of compound $11(1.25 \mathrm{~g})$ in $\mathrm{Et}_{2} \mathrm{O}(10 \mathrm{~mL})$ and $\mathrm{MeOH}(10 \mathrm{~mL})$ at room temperature. After stirring for $22 \mathrm{~h}$ at room temperature, Amberlite IR-120 ( $\mathrm{H}^{+}$form) was added, and the reaction mixture was neutralized. After filtration, the filtrate was evaporated. The residue was partitioned between $\mathrm{MeOH}$ and FC-72 (×3). The combined FC-72 layers were evaporated to give the fluorous compound 5b (1.05 g, 81\% in 4 steps from 7) as a white amorphous solid. The methanol layer was evaporated, and the residue was purified by column chromatography on silica gel $\left(\mathrm{CHCl}_{3}-\mathrm{MeOH}-\mathrm{H}_{2} \mathrm{O}=6: 4: 1\right)$ to give pure compound 12 (125 mg, 59\% in 4 steps from 7) as a white amorphous solid. Compound 12: $[\alpha]^{28}{ }_{\mathrm{D}}=34.3^{\circ}(\mathrm{c}=1.09$ in $\mathrm{MeOH}) ;{ }^{1} \mathrm{H}$ NMR $\left(600 \mathrm{MHz}, \mathrm{D}_{2} \mathrm{O}\right): \delta=3.26$ (s, 3H), 3.41 (t, $J=7.6 \mathrm{~Hz}$, 1H), 3.51 (dd, $J=10.0,3.4 \mathrm{~Hz}, 1 \mathrm{H}$ ), 3.55 (dd, $J=7.6,4.1 \mathrm{~Hz}, 1 \mathrm{H}), 3.62$ (m, 5H), 3.76 (m, 3H), 4.04 (d, $J=11.0 \mathrm{~Hz}, 1 \mathrm{H}), 4.29$ (d, $J=7.6 \mathrm{~Hz}, 1 \mathrm{H}), 4.60$ (s, 1H); ${ }^{13} \mathrm{C} \mathrm{NMR}\left(150 \mathrm{MHz}, \mathrm{CD}_{3} \mathrm{OD}\right): \delta=55.4,62.5$, 68.5, 69.9, 70.3, 71.9, 72.4, 72.6, 73.4, 74.8, 76.7, 102.8, 105.4; HRMS (ESI-TOF): Calcd for $\mathrm{C}_{13} \mathrm{H}_{24} \mathrm{O}_{11} \mathrm{Na}\left(\mathrm{M}+\mathrm{Na}^{+}\right)$: 379.1211, Found: 379.1220 .

Compound 5b: ${ }^{1} \mathrm{H}$ NMR (400 MHz, $\left.\mathrm{CDCl}_{3}\right): \delta=1.87$ (m, 2H), $2.10(\mathrm{~m}, 2 \mathrm{H}), 2.62$ (m, 6H), 3.45 (m, 2H), 3.64 (m, 2H), 3.69 and 3.72 (each s, 3H, sprits of O-Me peak); MALDI-TOF-MS: Calcd for $\mathrm{C}_{26} \mathrm{H}_{18} \mathrm{~F}_{34} \mathrm{NO}_{3}\left(\mathrm{M}+\mathrm{H}^{+}\right)$: 1038.1, Found: 1038.5; Calcd for $\mathrm{C}_{26} \mathrm{H}_{17} \mathrm{~F}_{34} \mathrm{NO}_{3} \mathrm{Na}\left(\mathrm{M}+\mathrm{Na}^{+}\right)$: 1060.1, Found: 1060.2.

Compound 14: $\quad$ Molecular sieves 4A powder (7.2 g) was added to a solution of compound 9 (7.01 g) and 13 (7.52 g, $10.9 \mathrm{mmol})$ in dry ether (100 mL)-dry EtOC $\mathrm{F}_{9}(60 \mathrm{~mL})$ under an argon atmosphere. After stirring for $2 \mathrm{~h}$ at $0{ }^{\circ} \mathrm{C}$, TMS-OTf $(1.20 \mathrm{~mL}, 6.63 \mathrm{mmol})$ was added to the reaction mixture at 0 ${ }^{\circ} \mathrm{C}$. After stirring for $40 \mathrm{~min}$ at $0{ }^{\circ} \mathrm{C}$, triethylamine $(1.0 \mathrm{~mL})$ was added to the reaction mixture. The reaction mixture was filtered on Celite, and washed with AcOEt. The filtrate was then evaporated. The residue was partitioned between $\mathrm{MeOH}$ and FC-72 $(\times 3)$. The combined FC-72 layers were 
evaporated to give the fluorous compound 14 (8.29 g). The fluorous compound 14 was used in the next step without further purification. The authentic sample was obtained as a white amorphous solid by purifying part of the sample (silica gel column chromatography; Hexane-AcOEt, 2:1). $R_{f}=0.50$ (Hexane : AcOEt = $3: 2) ;[\alpha]^{28}=3.5^{\circ}$ (c=1.00 in FC-72); ${ }^{1} \mathrm{H}$ NMR $\left(400 \mathrm{MHz}, \mathrm{CDCl}_{3}\right): \delta=1.04$ (s, 9H), 1.85 (m, 6H), 1.90 (s, 3H), 1.98 (s, 3H), 2.05 (s, 3H), 2.09 (m, 6H), 2.47-2.81 (m, 18H), 3.41 (s, 3H), 3.47-3.68 (m, 14H), 3.73 (brs, 2H), 3.91 (m, 1H), 4.02 (m, 1H), 4.48 (m, 1H), 4.73 (brs, 1H), 5.07 (m, 2H), $5.21(\mathrm{~m}, 3 \mathrm{H}), 5.30(\mathrm{~m}, 1 \mathrm{H}), 7.38(\mathrm{~m}, 6 \mathrm{H}), 7.67(\mathrm{~m}, 4 \mathrm{H})$; MALDI-TOF-MS: Calcd for $\mathrm{C}_{110} \mathrm{H}_{87} \mathrm{~F}_{102} \mathrm{~N}_{3} \mathrm{O}_{20} \mathrm{SiNa}\left(\mathrm{M}+\mathrm{Na}^{+}\right)$: 3758.4, Found: 3756.4; Calcd for $\mathrm{C}_{110} \mathrm{H}_{87} \mathrm{~F}_{102} \mathrm{~N}_{3} \mathrm{O}_{20} \mathrm{SiK}\left(\mathrm{M}+\mathrm{K}^{+}\right)$: 3774.4, Found: 3772.2.

Compound 15: To a solution of compound 14 (5.16 g) in dry THF (75 mL) was added 70\% HFpyridine $(7.5 \mathrm{~mL})$ at room temperature. After stirring for $17 \mathrm{~h}$ at room temperature, the reaction mixture was partitioned between toluene, saturated aqueous $\mathrm{NaHCO}_{3}$, and FC-72 $(\times 3)$. The combined FC-72 layers were washed with brine, dried over anhydrous $\mathrm{Na}_{2} \mathrm{SO}_{4}$, and evaporated to give the fluorous compound 15 (4.83 g). The fluorous compound 15 was used in the next step without further purification. The authentic sample was obtained as a white amorphous solid by purifying part of the sample (silica gel column chromatography; Hexane-AcOEt, $1: 1) . \mathrm{R}_{\mathrm{f}}=0.16$ (Hexane : AcOEt $=1: 1$ ); $[\alpha]^{28}{ }_{\mathrm{D}}=1.9^{\circ}$ (c=1.01 in FC-72); ${ }^{1} \mathrm{H}$ NMR (400 MHz, $\left.\mathrm{CDCl}_{3}\right): \delta=1.87$ (m, 6H), 2.00 (s, 3H), 2.04 (s, 3H), 2.05 (s, 3H), 2.10 (m, 6H), 2.45-2.80 (m, 19H), 3.39 (s, 3H), 3.43-3.72 (m, 16H), 3.92 (m, 2H), 4.54 (m, 1H), 4.70 (brs, 1H), 5.00 (m, 2H), 5.25 (m, 4H). MALDI-TOF-MS: Calcd for $\mathrm{C}_{94} \mathrm{H}_{69} \mathrm{~F}_{102} \mathrm{~N}_{3} \mathrm{O}_{20} \mathrm{Na}\left(\mathrm{M}+\mathrm{Na}^{+}\right)$: 3520.3, Found: 3520.2; Calcd for $\mathrm{C}_{94} \mathrm{H}_{69} \mathrm{~F}_{102} \mathrm{~N}_{3} \mathrm{O}_{20} \mathrm{~K}\left(\mathrm{M}+\mathrm{K}^{+}\right)$: 3536.2, Found: 3536.2.

Compound 16: $\quad$ Molecular sieves 4A powder (6.2 g) was added to a solution of compound 15 (4.35 g) and 13 (4.29 g, $6.23 \mathrm{mmol})$ in dry ether $(60 \mathrm{~mL})$-dry $\mathrm{EtOC}_{4} \mathrm{~F}_{9}(35 \mathrm{~mL})$ under an argon atmosphere. After stirring for $2.5 \mathrm{~h}$ at $0{ }^{\circ} \mathrm{C}$, TMS-OTf $(0.68 \mathrm{~mL}, 3.76 \mathrm{mmol})$ was added to the reaction mixture at 0 ${ }^{\circ} \mathrm{C}$. After stirring for $30 \mathrm{~min}$ at $0{ }^{\circ} \mathrm{C}$, triethylamine $(0.57 \mathrm{~mL})$ was added to the reaction mixture. The reaction mixture was filtered on Celite, and washed with AcOEt. The filtrate was then evaporated. The residue was partitioned between $\mathrm{MeOH}$ and FC-72 $(\times 3)$. The combined FC-72 layers were evaporated to give the fluorous compound 16 (5.09 g). The fluorous compound 16 was used in the next step without further purification. The authentic sample was obtained as a white amorphous solid by purifying part of the sample (silica gel column chromatography; Hexane-AcOEt, $13: 7$ ). $\quad \mathrm{R}_{\mathrm{f}}=0.64$ (Hexane : AcOEt = $1: 1) ;[\alpha]^{28}=4.5^{\circ}\left(\mathrm{c}=1.02\right.$ in AcOEt); ${ }^{1} \mathrm{H}$ NMR $\left(600 \mathrm{MHz}, \mathrm{CDCl}_{3}\right): \delta=1.04(\mathrm{~s}$, 9H), 1.88 (s, 3H), 1.90 (m, 6H), 1.93 (s, 3H), 1.98 (s, 6H), 2.05 (s, 3H), 2.06 (s, 3H), 2.08 (m, 6H), 2.56 (m, 13H), 2.72 (m, 5H), 3.30-3.80 (m, 21H), 4.07 (m, 1H), 4.50 (m, 2H), 4.74 (brs, 1H), 4.87-5.31 (m, 
9H), $7.40(\mathrm{~m}, 6 \mathrm{H}), 7.65(\mathrm{~m}, 4 \mathrm{H})$. MALDI-TOF-MS: Calcd for $\mathrm{C}_{122} \mathrm{H}_{103} \mathrm{~F}_{102} \mathrm{~N}_{3} \mathrm{O}_{28} \mathrm{SiNa}\left(\mathrm{M}+\mathrm{Na}^{+}\right)$: 4046.5, Found: 4045.1.

Compound 17: To a solution of compound 16 (2.68 g) in dry THF (40 mL) was added 70\% HFpyridine $(4.0 \mathrm{~mL})$ at room temperature. After stirring for $19 \mathrm{~h}$ at room temperature, the reaction mixture was partitioned between toluene, saturated aqueous $\mathrm{NaHCO}_{3}$, and $\mathrm{FC}-72(\times 3)$. The combined FC-72 layers were washed with brine, dried over anhydrous $\mathrm{Na}_{2} \mathrm{SO}_{4}$, and evaporated to give the fluorous compound 17 (2.62 g). The fluorous compound 17 was used in the next step without further purification. The authentic sample was obtained as a white amorphous solid by purifying part of the sample (silica gel column chromatography; Hexane-AcOEt, $4: 5) . \quad \mathrm{R}_{\mathrm{f}}=0.11$ (Hexane : AcOEt $=1$ : 1); $[\alpha]^{28}{ }_{\mathrm{D}}=1.4^{\mathrm{o}}$ (c=1.00 in AcOEt); ${ }^{1} \mathrm{H}$ NMR (400 MHz, $\left.\mathrm{CDCl}_{3}\right): \delta=1.89(\mathrm{~m}, 6 \mathrm{H}), 1.97$ (s, 3H), 2.00 (s, 3H), 2.03 (s, 6H), 2.04 (s, 6H), 2.05 (m, 6H), 2.46-2.88 (m, 19H), 3.40 (s, 3H), 3.43-3.71 (m, 18H), 3.91 (m, 2H), 4.00 (m, 1H), 4.50 (m, 2H), 4.72 (brs, 1H), 4.98 (m, 4H), 5.23 (m, 5H). MALDITOF-MS: Calcd for $\mathrm{C}_{106} \mathrm{H}_{85} \mathrm{~F}_{102} \mathrm{~N}_{3} \mathrm{O}_{28} \mathrm{Na} \quad\left(\mathrm{M}+\mathrm{Na}^{+}\right)$: 3808.4, Found: 3807.1; Calcd for $\mathrm{C}_{106} \mathrm{H}_{85} \mathrm{~F}_{102} \mathrm{~N}_{3} \mathrm{O}_{28} \mathrm{~K}\left(\mathrm{M}+\mathrm{K}^{+}\right)$: 3824.3, Found: 3823.9.

Compound 18: Molecular sieves 4A powder (3.1 g) was added to a solution of compound 17 (2.22 g) and 13 (2.02 g, $2.93 \mathrm{mmol}$ ) in dry ether (30 mL)-dry EtOC ${ }_{4} \mathrm{~F}_{9}(18 \mathrm{~mL})$ under an argon atmosphere. After stirring for $3.5 \mathrm{~h}$ at $0{ }^{\circ} \mathrm{C}$, TMS-OTf $(0.32 \mathrm{~mL}, 1.77 \mathrm{mmol})$ was added to the reaction mixture at 0 ${ }^{\circ} \mathrm{C}$. After stirring for $40 \mathrm{~min}$ at $0{ }^{\circ} \mathrm{C}$, triethylamine $(0.27 \mathrm{~mL})$ was added to the reaction mixture. The reaction mixture was filtered on Celite, and washed with AcOEt. The filtrate was then evaporated. The residue was partitioned between $\mathrm{MeOH}$ and FC-72 $(\times 3)$. The combined FC-72 layers were evaporated to give the fluorous compound 18 (2.33 g). The fluorous compound 18 was used in the next step without further purification. The authentic sample was obtained as a white amorphous solid by purifying part of the sample (silica gel column chromatography; Hexane-AcOEt, 3:2 ). $\quad R_{f}=0.52$ (Hexane : AcOEt = $1: 1) ;[\alpha]^{28}=3.3^{\circ}\left(\mathrm{c}=1.02\right.$ in AcOEt); ${ }^{1} \mathrm{H}$ NMR $\left(600 \mathrm{MHz}, \mathrm{CDCl}_{3}\right): \delta=1.04(\mathrm{~s}$, 9H), 1.73-2.26 (m, 39H), 2.24-2.93 (m, 18H), 3.31-3.70 (m, 23H), 3.72-4.12 (m, 4H), 4.50 (m, 3H), $4.74(\mathrm{~m}, 1 \mathrm{H}), 4.85-5.38(\mathrm{~m}, 12 \mathrm{H}), 7.40(\mathrm{~m}, 6 \mathrm{H}), 7.65(\mathrm{~m}, 4 \mathrm{H})$; MALDI-TOF-MS: Calcd for $\mathrm{C}_{134} \mathrm{H}_{119} \mathrm{~F}_{102} \mathrm{~N}_{3} \mathrm{O}_{36} \mathrm{SiNa}\left(\mathrm{M}+\mathrm{Na}^{+}\right)$: 4334.6, Found: 4337.2; Calcd for $\mathrm{C}_{134} \mathrm{H}_{119} \mathrm{~F}_{102} \mathrm{~N}_{3} \mathrm{O}_{36} \mathrm{SiK}\left(\mathrm{M}+\mathrm{K}^{+}\right)$: 4350.5, Found: 4352.2

Compound 19: To a solution of compound 18 (1.66 g) in dry THF (25 mL) was added 70\% HFpyridine $(2.5 \mathrm{~mL})$ at room temperature. After stirring for $20 \mathrm{~h}$ at room temperature, the reaction mixture was partitioned between toluene, saturated aqueous $\mathrm{NaHCO}_{3}$, and $\mathrm{FC}-72(\times 4)$. The combined FC-72 layers were washed with brine, dried over anhydrous $\mathrm{Na}_{2} \mathrm{SO}_{4}$, and evaporated. The residue was purified as a white amorphous solid by column chromatography on silica gel (Hexane-AcOEt, 3:4) to 
give pure compound 19 (195 mg, $11 \%$ in 8 steps from 7). $\mathrm{R}_{\mathrm{f}}=0.38$ (Hexane : AcOEt = $1: 2$ ); $[\alpha]^{28}$ $=0.1^{\circ}$ (c = 1.85 in AcOEt); ${ }^{1} \mathrm{H}$ NMR (600 MHz, $\left.\mathrm{CDCl}_{3}\right): \delta=1.70-2.26(\mathrm{~m}, 39 \mathrm{H}), 2.37-2.92(\mathrm{~m}, 18 \mathrm{H})$, 3.31-3.81 (m, 23H), 3.87 (m, 3H), 4.04 (m, 1H), 4.51 (m, 2H), 4.60 (m, 1H), 4.72 (m, 1H), 4.84-5.09 (m, 6H), 5.12-5.38 (m, 6H); MALDI-TOF-MS: Calcd for $\mathrm{C}_{118} \mathrm{H}_{101} \mathrm{~F}_{102} \mathrm{~N}_{3} \mathrm{O}_{36} \mathrm{Na}\left(\mathrm{M}+\mathrm{Na}^{+}\right)$: 4096.4, Found: 4094.6; Calcd for $\mathrm{C}_{118} \mathrm{H}_{101} \mathrm{~F}_{102} \mathrm{~N}_{3} \mathrm{O}_{36} \mathrm{~K}\left(\mathrm{M}+\mathrm{K}^{+}\right)$: 4112.4, Found: 4111.2.

Compound 20: A sodium methoxide solution in methanol (28\%, one drop) was added to a solution of compound $19(116 \mathrm{mg}, 28.6 \mu \mathrm{mol})$ in $\mathrm{Et}_{2} \mathrm{O}(2 \mathrm{~mL})$ and $\mathrm{MeOH}(2 \mathrm{~mL})$ at room temperature. After stirring for $18 \mathrm{~h}$ at room temperature, Amberlite IR-120 ( $\mathrm{H}^{+}$form) was added, and the reaction mixture was neutralized. After filtration, the filtrate was evaporated. The residue was partitioned between AcOEt and $\mathrm{H}_{2} \mathrm{O}(\times 3)$. The combined $\mathrm{H}_{2} \mathrm{O}$ layers were evaporated, and the residue was purified by column chromatography on Sephadex LH-20 (MeOH : $\left.\mathrm{H}_{2} \mathrm{O}=1: 1\right)$ to give pure compound 20 (19.2 mg, $99 \%)$ as a white amorphous solid. $[\alpha]^{28}{ }_{\mathrm{D}}=-10.4^{\mathrm{o}}\left(\mathrm{c}=1.29\right.$ in $\left.\mathrm{H}_{2} \mathrm{O}\right) ;{ }^{1} \mathrm{H}$ NMR $\left(600 \mathrm{MHz}, \mathrm{D}_{2} \mathrm{O}\right)$ : $\delta=3.28(\mathrm{~m}, 4 \mathrm{H}), 3.36(\mathrm{~m}, 4 \mathrm{H}), 3.44(\mathrm{~m}, 6 \mathrm{H}), 3.58(\mathrm{~m}, 2 \mathrm{H}), 3.70(\mathrm{~m}, 4 \mathrm{H}), 3.86(\mathrm{~m}, 5 \mathrm{H}), 4.47$ (d, $J=$ $8.2 \mathrm{~Hz}, 1 \mathrm{H}), 4.48$ (d, $J=8.9 \mathrm{~Hz}, 1 \mathrm{H}), 4.49$ (d, $J=7.7 \mathrm{~Hz}, 1 \mathrm{H}), 4.71$ (s, 1H); ${ }^{13} \mathrm{C}$ NMR $(150 \mathrm{MHz}$, $\left.\mathrm{D}_{2} \mathrm{O}\right): \delta=54.88,60.62,66.37,68.47,68.63,68.79,69.28,69.35,69.52,69.73,70.32,71.34,72.94$, 72.98, 74.84, 75.38, 75.46, 75.55, 75.81, 100.87, 102.76, 102.79, 102.86; HRMS (ESI-TOF): Calcd for $\mathrm{C}_{25} \mathrm{H}_{44} \mathrm{O}_{21} \mathrm{Na}\left(\mathrm{M}+\mathrm{Na}^{+}\right)$: 703.2267, Found: 703.2287.

Compound 22: TBDPS-Cl (17.2 mL, $68.1 \mathrm{mmol})$ was added to a solution of compound $21^{18}$ (10.0 g, $45.4 \mathrm{mmol})$ in pyridine $(100 \mathrm{~mL})$ at room temperature. After stirring for $4 \mathrm{~h}$ at room temperature, acetic anhydride ( $42.8 \mathrm{~mL}, 454 \mathrm{mmol}$ ) was added to the reaction mixture. After stirring for $19 \mathrm{~h}$ at room temperature, methanol $(80 \mathrm{~mL})$ was added to the reaction mixture at $0{ }^{\circ} \mathrm{C}$. Almost of methanol was evaporated off. The residue was added to water, and extracted three times with AcOEt. The combined AcOEt layers were washed with brine, dried over anhydrous $\mathrm{Na}_{2} \mathrm{SO}_{4}$, and evaporated. The residue was purified by column chromatography on silica gel (Hexane-EtOAc $=3: 1$ ) to give compound $22\left(24.9\right.$ g, 93\%) as colorless plate crystals. m.p. $=117-118^{\circ} \mathrm{C} .[\alpha]^{23}{ }_{\mathrm{D}}=-22.2^{\circ}(\mathrm{c}=1.01$ in $\mathrm{CHCl}_{3}$ ). $\quad{ }^{1} \mathrm{H}$ NMR (600 MHz, $\left.\mathrm{CDCl}_{3}\right): \delta=1.03$ (s, 9H), 1.99 (s, 3H), 2.01 (s, 3H), 2.05 (s, 3H), 3.67 (m, 1H), 3.76 (m, 2H), 4.05 (dd, $J=14.4,6.2 \mathrm{~Hz}, 1 \mathrm{H}), 4.30$ (dd, $J=14.4,4.8 \mathrm{~Hz}, 1 \mathrm{H}), 4.48$ (d, $J=$ $8.2 \mathrm{~Hz}, 1 \mathrm{H}), 5.05$ (dd, $J=10.3,3.4 \mathrm{~Hz}, 1 \mathrm{H}), 5.21$ (m, 3H), 5.55 (d, $J=3.4 \mathrm{~Hz}, 1 \mathrm{H}), 5.81$ (m, 1H), 7.41 (m, 6H), $7.62(\mathrm{~m}, 4 \mathrm{H}) ;{ }^{13} \mathrm{C}$ NMR (150 MHz, $\left.\mathrm{CDCl}_{3}\right): \delta=19.04,20.63,20.65,20.78,26.71,61.26$, 67.13, 69.24, 69.78, 71.30, 73.39, 100.06, 117.38, 127.79, 129.83, 129.90, 132.81, 133.01, 133.45, 135.57, 135.62, 169.48, 170.12, 170.21; Anal. Calcd for $\mathrm{C}_{31} \mathrm{H}_{40} \mathrm{O}_{9} \mathrm{Si}$ : C, 63.68; H, 6.90. Found: C, 63.50; H, 7.02. 
Compound 23: $\mathrm{Pd}\left(\mathrm{PPh}_{3}\right)_{4}(10.0 \mathrm{~g}, 8.65 \mathrm{mmol})$ was added to a solution of compound 22 (24.6 g, $42.1 \mathrm{mmol})$ in $\mathrm{AcOH}(200 \mathrm{~mL})$ under an argon atmosphere. After stirring for $1 \mathrm{~h}$ at $80{ }^{\circ} \mathrm{C}$, toluene (8 $0 \mathrm{~mL}$ ) was added to the reaction mixture at room temperature. The reaction mixture was then evaporated. The residue was purified by column chromatography on silica gel (Hexane-EtOAc $=2: 1$ ) to give a deallylated compound (18.3 g, 80\%). DBU (1.50 mL, $10.0 \mathrm{mmol})$ and trichloroacetonitrile (20.0 mL, $202 \mathrm{mmol}$ ) were added to a solution of the above deallylated compound (18.3 g, $33.6 \mathrm{mmol}$ ) in dry $\mathrm{CH}_{2} \mathrm{Cl}_{2}(50 \mathrm{~mL})$ at $0{ }^{\circ} \mathrm{C}$. After stirring for $1 \mathrm{~h}$ at $0{ }^{\circ} \mathrm{C}$, the reaction mixture was purified by column chromatography on silica gel (Hexane-EtOAc $=3: 1)$ to give compound $23(20.4 \mathrm{~g}, 88 \%)$ as a white amorphous solid. $[\alpha]^{23}=49.5^{\circ}$ (c $=1.00$ in $\left.\mathrm{CHCl}_{3}\right) .{ }^{1} \mathrm{H}$ NMR $\left(400 \mathrm{MHz}, \mathrm{CDCl}_{3}\right): \delta=1.00$ (s, 9H), 2.02 (s, 3H), 2.03 (s, 3H), 2.05 (s, 3H), 3.63 (dd, $J=10.0,7.8 \mathrm{~Hz}, 1 \mathrm{H}$ ), 3.71 (dd, $J=10.0,6.1 \mathrm{~Hz}$, 1H), 4.31 (t, $J=7.3 \mathrm{~Hz}, 1 \mathrm{H}$ ), 5.32 (dd, $J=11.0,3.7 \mathrm{~Hz}, 1 \mathrm{H}$ ), 5.46 (dd, $J=11.0,3.2 \mathrm{~Hz}, 1 \mathrm{H}$ ), 5.73 (d, $J$ $=3.2 \mathrm{~Hz}, 1 \mathrm{H}), 6.55(\mathrm{~d}, J=3.7 \mathrm{~Hz}, 1 \mathrm{H}), 7.37$ (m, 6H), $7.58(\mathrm{~m}, 4 \mathrm{H}), 8.60$ (brs, $1 \mathrm{H}) ;{ }^{13} \mathrm{C}$ NMR $(100$ $\left.\mathrm{MHz}, \mathrm{CDCl}_{3}\right): \delta=19.11,20.61,20.77,26.70,61.24,67.22,67.41,67.84,71.47,93.56,127.64,127.67$, 129.71, 129.76, 132.74, 132.78, 135.44, 160.84, 169.77, 169.82, 169.99; $\quad$ MALDI-TOF-MS: Calcd for $\mathrm{C}_{30} \mathrm{H}_{36} \mathrm{Cl}_{3} \mathrm{NO}_{9} \mathrm{SiNa}\left(\mathrm{M}+\mathrm{Na}^{+}\right)$: 710.1, Found: 710.0 .

Compound 25: $\quad$ DMAP (2.54 g, $20.8 \mathrm{mmol})$ and DCC (6.42 g, $31.1 \mathrm{mmol})$ were added to a solution of compound $24^{19}$ (2.66 g, $\left.5.2 \mathrm{mmol}\right)$ and $\mathbf{6}(16.5 \mathrm{~g}, 16.1 \mathrm{mmol})$ in dry $\mathrm{CH}_{2} \mathrm{Cl}_{2}(140 \mathrm{~mL})$. After stirring for $2 \mathrm{~h}$ at room temperature, toluene $(100 \mathrm{~mL})$ was added to the reaction mixture. Almost all of the $\mathrm{CH}_{2} \mathrm{Cl}_{2}$ was evaporated off, and the reaction mixture was extracted three times with FC-72. The combined FC-72 layers were evaporated to give the fluorous compound 25 (17.6 g). The fluorous compound $\mathbf{2 5}$ was used in the next step without further purification. The authentic sample was obtained by purifying part of the sample (silica gel column chromatography; hexane-AcOEt $=5: 2$ ). Colorless oil; $\mathrm{R}_{\mathrm{f}}=0.50$ (Hexane : AcOEt $\left.=2: 1\right) ;[\alpha]^{23}{ }_{\mathrm{D}}=-5.5^{\circ}\left(\mathrm{c}=1.01\right.$ in FC-72). ${ }^{1} \mathrm{H}$ NMR $(400$ $\left.\mathrm{MHz} \mathrm{CDCl}_{3}\right): \delta=1.82(\mathrm{~m}, 6 \mathrm{H}), 2.08(\mathrm{~m}, 6 \mathrm{H}), 2.51$ (m, 18H), $3.13(\mathrm{~m}, 1 \mathrm{H}), 3.42(\mathrm{~m}, 13 \mathrm{H}), 3.77(\mathrm{~m}$, 1H), $4.51(\mathrm{~m}, 1 \mathrm{H}), 4.58(\mathrm{~m}, 1 \mathrm{H}), 4.86(\mathrm{~m}, 1 \mathrm{H}), 5.02(\mathrm{~m}, 1 \mathrm{H}), 5.16(\mathrm{~m}, 1 \mathrm{H}), 5.59(\mathrm{~m}, 1 \mathrm{H}), 7.31(\mathrm{~m}$, 20H); MALDI-TOF-MS: Calcd for $\mathrm{C}_{107} \mathrm{H}_{71} \mathrm{~F}_{102} \mathrm{~N}_{3} \mathrm{O}_{12} \mathrm{Na}\left(\mathrm{M}+\mathrm{Na}^{+}\right)$: 3550.3, Found: 3550.4.

Compound 26: (+)-Camphorsulfonic acid (4.21 g, $18.1 \mathrm{mmol}$ ) and lithium chloride (769 mg, 18.1 mmol) were added to a solution of compound 25 (6.40 g) in $\mathrm{CHCl}_{3}(100 \mathrm{~mL})-\mathrm{MeOH}(50 \mathrm{~mL})$. After stirring for $3 \mathrm{~h}$ at room temperature, the reaction mixture was added to saturated aqueous $\mathrm{NaHCO}_{3}$, and extracted three times with AcOEt. The combined AcOEt layers were washed with brine, dried over anhydrous $\mathrm{Na}_{2} \mathrm{SO}_{4}$, and evaporated. The residue was partitioned between toluene and $\mathrm{FC}-72(\times 3)$. The combined FC-72 layers were evaporated to give the fluorous compound 26 (5.73 g). The fluorous compound 26 was used immediately in the next step without further purification. 
Compound 27: Molecular sieves 4A powder (4.0 g) was added to a solution of compound 26 (4.39 g) and 23 (4.60 g, $6.68 \mathrm{mmol})$ in dry ether $(70 \mathrm{~mL})$-dry EtOC $\mathrm{F}_{9}(40 \mathrm{~mL})$ under an argon atmosphere. After stirring for $3 \mathrm{~h}$ at $0{ }^{\circ} \mathrm{C}$, TMS-OTf $(726 \mu \mathrm{L}, 4.01 \mathrm{mmol})$ was added to the reaction mixture at $0{ }^{\circ} \mathrm{C}$. After stirring for $30 \mathrm{~min}$ at $0{ }^{\circ} \mathrm{C}$, triethylamine $(1.0 \mathrm{~mL})$ was added to the reaction mixture. The reaction mixture was filtered on Celite. The filtrate was added to saturated aqueous $\mathrm{NaHCO}_{3}$, and extracted three times with AcOEt. The combined AcOEt layers were washed with brine, dried over anhydrous $\mathrm{Na}_{2} \mathrm{SO}_{4}$, and evaporated. The residue was partitioned between $\mathrm{MeOH}$ and $\mathrm{FC}-72(\times 3)$. The combined FC-72 layer was evaporated to give the fluorous compound 27 (5.05 g). The fluorous compound 27 was used in the next step without further purification. The authentic sample was obtained as a white amorphous solid by purifying part of the sample (silica gel column chromatography; Hexane-AcOEt, $2: 1$ ). $\mathrm{R}_{\mathrm{f}}=0.40$ (Hexane : AcOEt $=3: 2$ ); $[\alpha]^{23}{ }_{\mathrm{D}}=-0.5^{\circ}(\mathrm{c}=1.00$ in FC-72). ${ }^{1} \mathrm{H}$ NMR (400 MHz, $\left.\mathrm{CDCl}_{3}\right): \delta=1.03$ (s, 9H), 1.86 (m, 6H), 1.98 (s, 3H), 2.02 (s, 6H), 2.04 (m, 6H), 2.50 (m, 18H), 3.39-3.79 (m, 18H), 4.54 (m, 3H), 4.96 (m, 3H), 5.17 (m, 2H), 5.32 (m, 1H), $5.57(\mathrm{~d}, \quad J=2.4 \mathrm{~Hz}, 1 \mathrm{H}), 7.36(\mathrm{~m}, 11 \mathrm{H}), 7.61(\mathrm{~m}, 4 \mathrm{H})$. MALDI-TOF-MS: Calcd for $\mathrm{C}_{116} \mathrm{H}_{91} \mathrm{~F}_{102} \mathrm{~N}_{3} \mathrm{O}_{20} \mathrm{SiNa}\left(\mathrm{M}+\mathrm{Na}^{+}\right)$: 3834.4, Found: 3834.8. Calcd for $\mathrm{C}_{116} \mathrm{H}_{91} \mathrm{~F}_{102} \mathrm{~N}_{3} \mathrm{O}_{20} \mathrm{SiK}\left(\mathrm{M}+\mathrm{K}^{+}\right)$: 3850.4, Found: 3850.4.

Compound 28: To a solution of compound 27 (5.05 g) in dry THF (75 mL) was added 70\% HFpyridine $(7.5 \mathrm{~mL})$ at room temperature. After stirring for $9 \mathrm{~h}$ at room temperature, the reaction mixture was partitioned between toluene, saturated aqueous $\mathrm{NaHCO}_{3}$, and FC-72 $(\times 3)$. The combined FC-72 layers were washed with brine, dried over anhydrous $\mathrm{Na}_{2} \mathrm{SO}_{4}$, and evaporated to give the fluorous compound 28 (4.57 g). The fluorous compound 28 was used immediately in the next step without further purification.

Compound 29: Molecular sieves 4A powder (3.0 g) was added to a solution of compound 27 (2.32 g) and 23 (2.23 g, $3.25 \mathrm{mmol})$ in dry ether (27 mL)-dry EtOC ${ }_{4} \mathrm{~F}_{9}(15 \mathrm{~mL})$ under an argon atmosphere. After stirring for $2 \mathrm{~h}$ at $0{ }^{\circ} \mathrm{C}$, TMS-OTf (353 $\mu \mathrm{L}, 1.95 \mathrm{mmol}$ ) was added to the reaction mixture at $0{ }^{\circ} \mathrm{C}$. After stirring for $30 \mathrm{~min}$ at $0{ }^{\circ} \mathrm{C}$, triethylamine $(0.5 \mathrm{~mL})$ was added to the reaction mixture. The reaction mixture was filtered on Celite. The filtrate was added to saturated aqueous $\mathrm{NaHCO}_{3}$, and extracted three times with AcOEt. The combined AcOEt layers were washed with brine, dried over anhydrous $\mathrm{Na}_{2} \mathrm{SO}_{4}$, and evaporated. The residue was partitioned between $\mathrm{MeOH}$ and $\mathrm{FC}-72(\times 3)$. The combined FC-72 layer was evaporated to give the fluorous compound 29 (2.62 g). The fluorous compound 29 was used in the next step without further purification. The authentic sample was obtained as a white amorphous solid by purifying part of the sample (silica gel column 
chromatography; Hexane-AcOEt, $3: 2) . \quad R_{\mathrm{f}}=0.68$ (Hexane : AcOEt $\left.=1: 1\right) ;[\alpha]^{25}=-3.3^{0}(\mathrm{c}=1.01$ in FC-72). ${ }^{1} \mathrm{H}$ NMR (400 MHz, $\left.\mathrm{CDCl}_{3}\right): \delta=1.03$ (s, 9H), $1.88(\mathrm{~m}, 6 \mathrm{H}), 1.93(\mathrm{~s}, 3 \mathrm{H}), 1.98(\mathrm{~s}, 3 \mathrm{H}), 2.02$ (s, 6H), 2.03 (s, 3H), 2.07 (s, 3H), 2.08 (m, 6H), 2.46-2.77 (m, 18H), 3.36-3.87 (m, 21H), 4.52 (m, 4H), 4.97 (m, 4H), 5.13 (m, 2H), $5.23(\mathrm{~m}, 1 \mathrm{H}), 5.35$ (m, 2H), 5.58 (d, $J=2.4 \mathrm{~Hz}, 1 \mathrm{H}), 7.35$ (m, 11H), 7.60 (m, 4H). MALDI-TOF-MS: Calcd for $\mathrm{C}_{128} \mathrm{H}_{107} \mathrm{~F}_{102} \mathrm{~N}_{3} \mathrm{O}_{28} \mathrm{SiNa}\left(\mathrm{M}+\mathrm{Na}^{+}\right)$: 4122.5, Found: 4124.2; Calcd for $\mathrm{C}_{128} \mathrm{H}_{107} \mathrm{~F}_{102} \mathrm{~N}_{3} \mathrm{O}_{28} \mathrm{SiK}\left(\mathrm{M}+\mathrm{K}^{+}\right)$: 4138.5, Found: 4140.6.

Compound 30: To a solution of compound 29 (2.45 g) in dry THF (40 mL) was added 70\% HFpyridine $(4.0 \mathrm{~mL})$ at room temperature. After stirring for $9 \mathrm{~h}$ at room temperature, the reaction mixture was partitioned between toluene, saturated aqueous $\mathrm{NaHCO}_{3}$, and FC-72 $(\times 3)$. The combined FC-72 layers were washed with brine, dried over anhydrous $\mathrm{Na}_{2} \mathrm{SO}_{4}$, and evaporated to give the fluorous compound 30 (2.26 g). The fluorous compound $\mathbf{3 0}$ was used immediately in the next step without further purification.

Compound 31: Molecular sieves 4A powder (1.5 g) was added to a solution of compound 30 (1.30 g) and 23 (1.16 g, $1.68 \mathrm{mmol})$ in dry ether $(14 \mathrm{~mL})$-dry $\mathrm{EtOC}_{4} \mathrm{~F}_{9}(7 \mathrm{~mL})$ under an argon atmosphere. After stirring for $2 \mathrm{~h}$ at $0{ }^{\circ} \mathrm{C}$, TMS-OTf $(183 \mu \mathrm{L}, 1.01 \mathrm{mmol})$ was added to the reaction mixture at $0{ }^{\circ} \mathrm{C}$. After stirring for $30 \mathrm{~min}$ at $0{ }^{\circ} \mathrm{C}$, triethylamine $(0.5 \mathrm{~mL})$ was added to the reaction mixture. The reaction mixture was filtered on Celite. The filtrate was added to saturated aqueous $\mathrm{NaHCO}_{3}$, and extracted three times with AcOEt. The combined AcOEt layers were washed with brine, dried over anhydrous $\mathrm{Na}_{2} \mathrm{SO}_{4}$, and evaporated. The residue was partitioned between $\mathrm{MeOH}$ and $\mathrm{FC}-72(\times 3)$. The combined FC-72 layer was evaporated to give the fluorous compound 31 (1.39 g). The fluorous compound 31 was used in the next step without further purification. The authentic sample was obtained as a white amorphous solid by purifying part of the sample (silica gel column chromatography; Hexane-AcOEt, $5: 4) . \mathrm{R}_{\mathrm{f}}=0.56$ (Hexane : AcOEt $\left.=1: 1\right) ;[\alpha]^{25}=-1.7^{0}(\mathrm{c}=1.38$ in $\mathrm{CHCl}_{3}$ ). ${ }^{1} \mathrm{H}$ NMR (600 MHz, $\left.\mathrm{CDCl}_{3}\right): \delta=1.02$ (s, 9H), 1.87 (m, 6H), 1.91 (s, 3H), 1.95 (s, 3H), 1.97 (s, 3H), 2.00 (s, 3H), 2.03 (s, 9H), 2.05 (s, 3H), 2.10 (m, 6H), 2.12 (s, 3H), 2.43-2.76 (m, 18H), 3.343.88 (m, 24H), 4.43 (m, 2H), 4.57 (m, 3H), 4.96 (m, 5H), 5.15 (m, 4H), 5.31 (d, J = 3.4 Hz, 1H), 5.36 (brs, 2H), 5.56 (d, $J=3.4 \mathrm{~Hz}, 1 \mathrm{H}), 7.28-7.44$ (m, 11H), 7.60 (m, 4H); MALDI-TOF-MS: Calcd for $\mathrm{C}_{140} \mathrm{H}_{123} \mathrm{~F}_{102} \mathrm{~N}_{3} \mathrm{O}_{36} \mathrm{SiNa}\left(\mathrm{M}+\mathrm{Na}^{+}\right)$: 4410.6, Found: 4408.4; Calcd for $\mathrm{C}_{140} \mathrm{H}_{123} \mathrm{~F}_{102} \mathrm{~N}_{3} \mathrm{O}_{36} \mathrm{SiK}\left(\mathrm{M}+\mathrm{K}^{+}\right)$: 4426.6, Found: 4424.7.

Compound 32: To a solution of compound 31 (1.39 g) in dry THF (20 mL) was added 70\% HFpyridine $(2.0 \mathrm{~mL})$ at room temperature. After stirring for $8 \mathrm{~h}$ at room temperature, the reaction mixture was partitioned between toluene, saturated aqueous $\mathrm{NaHCO}_{3}$, and FC-72 $(\times 3)$. The combined FC-72 
layers were washed with brine, dried over anhydrous $\mathrm{Na}_{2} \mathrm{SO}_{4}$, and evaporated to give the fluorous compound 32 (1.30 g). The fluorous compound 32 was used immediately in the next step without further purification.

Compound 33: Molecular sieves 4A powder (1.0 g) was added to a solution of compound 32 (703 $\mathrm{mg})$ and 23 (1.17 g, $1.69 \mathrm{mmol})$ in dry ether $(8 \mathrm{~mL})$-dry $\mathrm{EtOC}_{4} \mathrm{~F}_{9}(4 \mathrm{~mL})$ under an argon atmosphere. After stirring for $2 \mathrm{~h}$ at $0{ }^{\circ} \mathrm{C}$, TMS-OTf $(92 \mu \mathrm{L}, 0.51 \mathrm{mmol})$ was added to the reaction mixture at $0{ }^{\circ} \mathrm{C}$. After stirring for $30 \mathrm{~min}$ at $0{ }^{\circ} \mathrm{C}$, triethylamine $(0.4 \mathrm{~mL})$ was added to the reaction mixture. The reaction mixture was filtered on Celite. The filtrate was added to saturated aqueous $\mathrm{NaHCO}_{3}$, and extracted three times with AcOEt. The combined AcOEt layers were washed with brine, dried over anhydrous $\mathrm{Na}_{2} \mathrm{SO}_{4}$, and evaporated. The residue was partitioned between $\mathrm{MeOH}$ and FC-72 $(\times 3)$. The combined FC-72 layer was evaporated. The residue was purified by column chromatography on silica gel $\left(\mathrm{EtOC}_{4} \mathrm{~F}_{9}\right.$ : Acetone $\left.=5: 2\right)$ to give compound 33 (285 mg, 29\%, in 9 steps) as a white amorphous solid. $\mathrm{R}_{\mathrm{f}}=0.39\left(\mathrm{EtOC}_{4} \mathrm{~F}_{9}\right.$ : Acetone $\left.=2: 1\right) ;[\alpha]^{25}{ }_{\mathrm{D}}=-9.9^{\circ}\left(\mathrm{c}=1.13\right.$ in $\left.\mathrm{CHCl}_{3}\right) ;{ }^{1} \mathrm{H}$ NMR (600 MHz, $\left.\mathrm{CDCl}_{3}\right): \delta=1.02$ (s, 9H), 1.87 (m, 6H), 1.92 (s, 3H), 1.946 (s, 3H), 1.949 (s, 3H), 1.98 (s, 3H), 2.00 (s, 3H), 2.02 (s, 12H), 2.04 (s, 3H), 2.07 (m, 6H), 2.11 (s, 3H), 2.13 (s, 3H), 2.40-2.76 (m, 18H), 3.39-3.87 (m, 27H), 4.43 (m, 3H), 4.56 (m, 3H), 4.96 (m, 6H), 5.11 (m, 4H), 5.21 (m, 1H), 5.31 (d, $J=3.4 \mathrm{~Hz}, 1 \mathrm{H}), 5.34(\mathrm{~m}, 3 \mathrm{H}), 5.56$ (d, $J=3.4 \mathrm{~Hz}, 1 \mathrm{H}), 7.28-7.44(\mathrm{~m}, 11 \mathrm{H}), 7.60$ (m, 4H); MALDI-TOF-MS: Calcd for $\mathrm{C}_{152} \mathrm{H}_{139} \mathrm{~F}_{102} \mathrm{~N}_{3} \mathrm{O}_{44} \mathrm{SiNa}\left(\mathrm{M}+\mathrm{Na}^{+}\right)$: 4698.7, Found: 4699.9. Calcd for $\mathrm{C}_{150} \mathrm{H}_{139} \mathrm{~F}_{102} \mathrm{~N}_{3} \mathrm{O}_{44} \mathrm{SiK}\left(\mathrm{M}+\mathrm{K}^{+}\right)$: 4714.7, Found: 4715.6 .

Compound 34: To a solution of compound 33 (208 mg, $45 \mu \mathrm{mol}$ ) in dry THF (4 mL) was added $70 \%$ HF-pyridine (400 $\mu \mathrm{L})$ at room temperature. After stirring for $22 \mathrm{~h}$ at room temperature, the reaction mixture was partitioned between toluene, saturated aqueous $\mathrm{NaHCO}_{3}$, and $\mathrm{FC}-72(\times 3)$. The combined FC-72 layers were washed with brine, dried over anhydrous $\mathrm{Na}_{2} \mathrm{SO}_{4}$, and evaporated to give the fluorous compound 34 (192 mg). The fluorous compound 34 was used immediately in the next step without further purification.

Compound 35: A sodium methoxide solution in methanol (28\%, $30 \mu \mathrm{L})$ was added to a solution of compound 34 (187 mg) in $\mathrm{Et}_{2} \mathrm{O}(6 \mathrm{~mL})$ and $\mathrm{MeOH}(18 \mathrm{~mL})$ at room temperature. After stirring for $2 \mathrm{~h}$ at room temperature, $\mathrm{H}_{2} \mathrm{O}(4 \mathrm{~mL})$ was added to the reaction mixture. After stirring for $1 \mathrm{~h}$ at room temperature, Amberlite IR-120 ( $\mathrm{H}^{+}$form) was added, and the reaction mixture was neutralized. After filtration, the filtrate was evaporated. The residue was partitioned between $\mathrm{H}_{2} \mathrm{O}$ and $\mathrm{EtOC}_{4} \mathrm{~F}_{9}(\times 2)$. The $\mathrm{H}_{2} \mathrm{O}$ layer was evaporated, and the residue was purified by column chromatography on ODS silica gel (10\% MeOH) to give compound 35 (35.8 mg, 92\% in 2 steps from 33) as a white amorphous solid. 
$[\alpha]^{25}{ }_{\mathrm{D}}=-16.5^{\mathrm{o}}\left(\mathrm{c}=0.41 \mathrm{in} \mathrm{H}_{2} \mathrm{O}\right) ;{ }^{1} \mathrm{H}$ NMR $\left(600 \mathrm{MHz}, \mathrm{D}_{2} \mathrm{O}\right): \delta=3.40(\mathrm{~m}, 5 \mathrm{H}), 3.50(\mathrm{~m}, 6 \mathrm{H}), 3.62(\mathrm{~m}$, 2H), 3.78 (m, 13H), 3.90 (m, 4H), 4.29 (d, $J=7.6 \mathrm{~Hz}, 1 \mathrm{H}), 4.30$ (d, $J=7.6 \mathrm{~Hz}, 1 \mathrm{H}), 4.31$ (d, $J=8.2 \mathrm{~Hz}$, 1H), 4.35 (d, $J=7.6 \mathrm{~Hz}, 1 \mathrm{H}), 4.36$ (d, $J=8.2 \mathrm{~Hz}, 1 \mathrm{H}), 4.62$ (d, $J=11.7 \mathrm{~Hz}, 1 \mathrm{H}), 4.82(\mathrm{~d}, J=11.7 \mathrm{~Hz}$, 1H), 7.31 (m, 5H); ${ }^{13} \mathrm{C}$ NMR (150 MHz, $\left.\mathrm{D}_{2} \mathrm{O}\right): \delta=61.63,69.23,69.28,69.75,69.85,69.94,70.02$, 71.29, 71.31, 71.35, 72.11, 73.18, 73.22, 73.24, 73.35, 73.40, 74.32, 74.34, 74.36, 74.49, 75.76, 102.53, 103.95, 104.01, 129.01, 129.18, 129.35, 137.45; HRMS (ESI-TOF): Calcd for $\mathrm{C}_{37} \mathrm{H}_{58} \mathrm{O}_{26} \mathrm{Na}\left(\mathrm{M}^{2} \mathrm{Na}^{+}\right)$: 941.3109, Found: 941.3148.

Compound 36: A solution of compound 35 (25.8 mg, $28 \mu \mathrm{mol})$ in EtOH (3 mL)- $\mathrm{H}_{2} \mathrm{O}(3 \mathrm{~mL})$ was added to a suspension of $10 \% \mathrm{Pd} / \mathrm{C}(25 \mathrm{mg})$ in $\mathrm{EtOH}(0.5 \mathrm{~mL})-\mathrm{H}_{2} \mathrm{O}(0.5 \mathrm{~mL})$. After a $2 \mathrm{~h}$ bubbling with hydrogen, the reaction mixture was filtered. The filtrate was evaporated, and the residue was purified by column chromatography on Sephadex LH-20 (50\% MeOH) to give compound 36 (18.8 mg, $81 \%$ ) as a white amorphous solid. The ratio of the $\alpha / \beta$ isomers was $1: 2$. $[\alpha]^{25}{ }_{\mathrm{D}}=10.9^{\circ}\left(\mathrm{c}=0.59\right.$ in $\mathrm{H}_{2} \mathrm{O}$ ); ${ }^{1} \mathrm{H}$ NMR (600 MHz, $\left.\mathrm{D}_{2} \mathrm{O}\right): \delta=3.32-3.92(\mathrm{~m}, 30 \mathrm{H}), 4.31(\mathrm{~m}, 4 \mathrm{H}), 4.44(\mathrm{~d}, J=8.2 \mathrm{~Hz}, \mathrm{H}-1$ of the $\beta$ isomer), 5.11 (d, $J=4.1 \mathrm{~Hz}, \mathrm{H}-1$ of the $\alpha$ isomer); ${ }^{13} \mathrm{C}$ NMR (150 MHz, $\left.\mathrm{D}_{2} \mathrm{O}\right): \delta=61.86,69.12,69.48$, 69.62, 69.78, 70.07, 70.13, 70.24, 70.32, 71.53, 71.58, 72.65, 73.36, 73.42, 73.45, 73.60, 74.60, 75.98, 93.20, 97.27, 103.98, 104.05, 104.19, 104.24; HRMS (ESI-TOF): Calcd for $\mathrm{C}_{30} \mathrm{H}_{52} \mathrm{O}_{26} \mathrm{Na}\left(\mathrm{M}^{2} \mathrm{Na}^{+}\right)$: 851.2645, Found: 851.2664. 


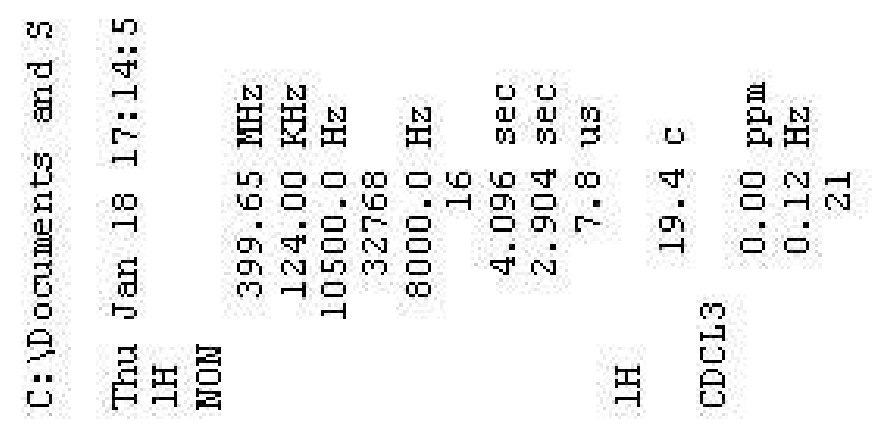

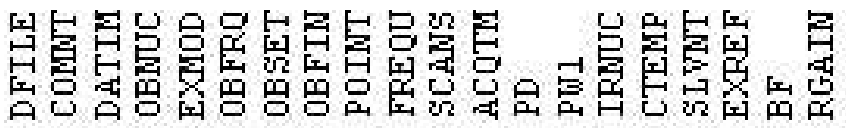

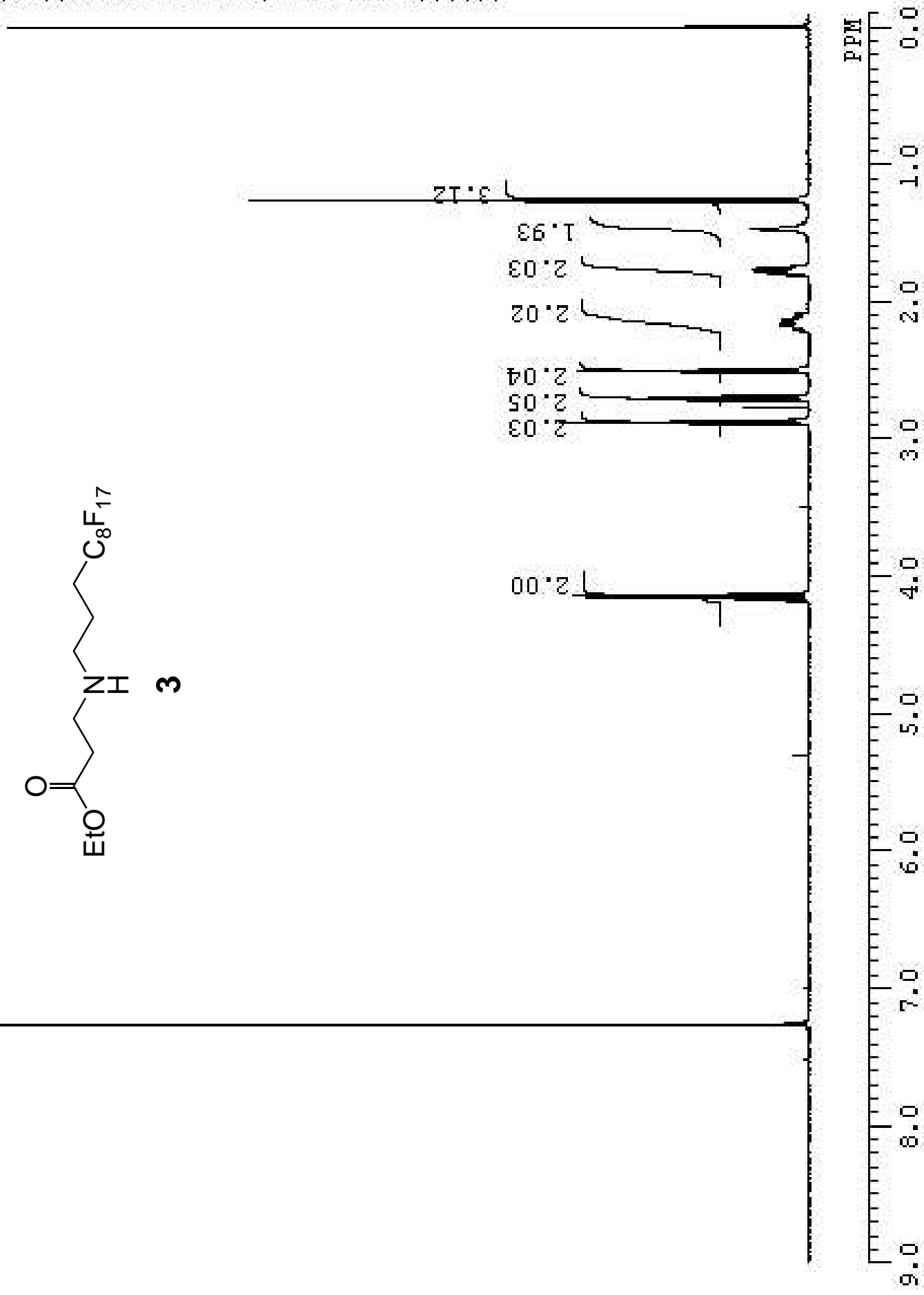




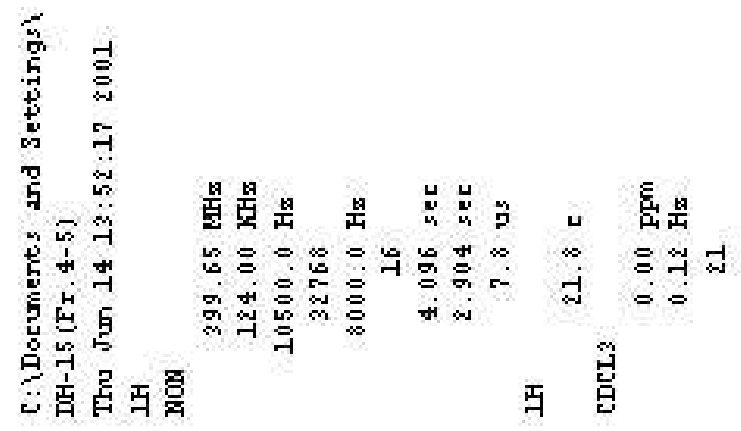

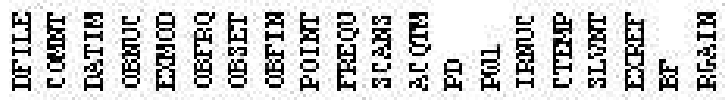

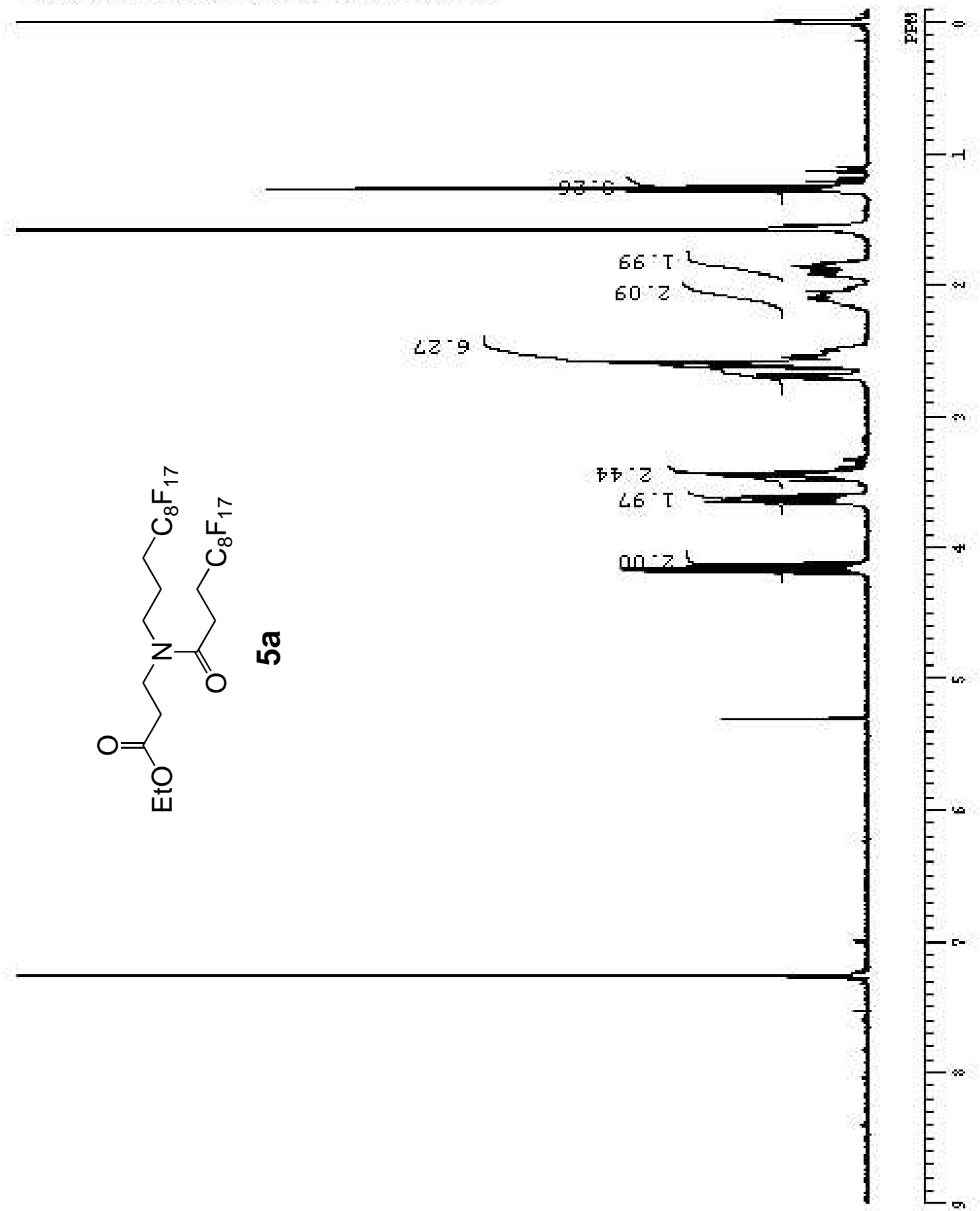




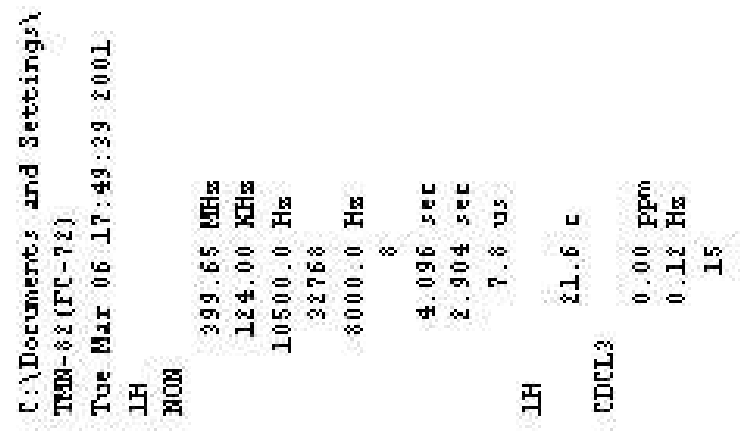

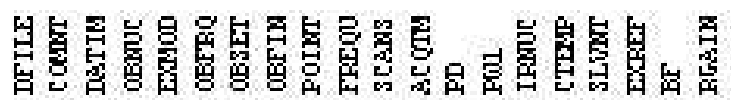

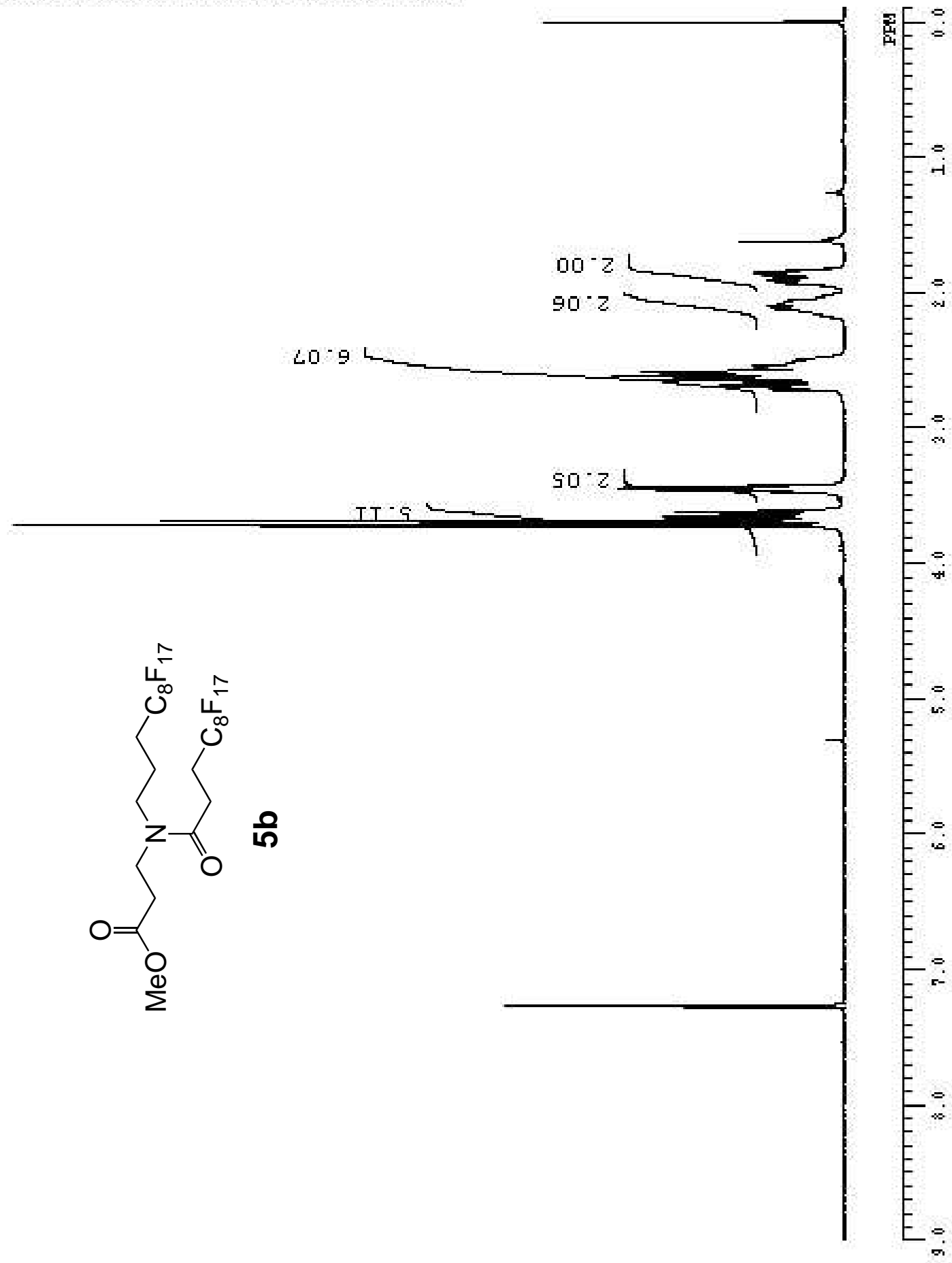




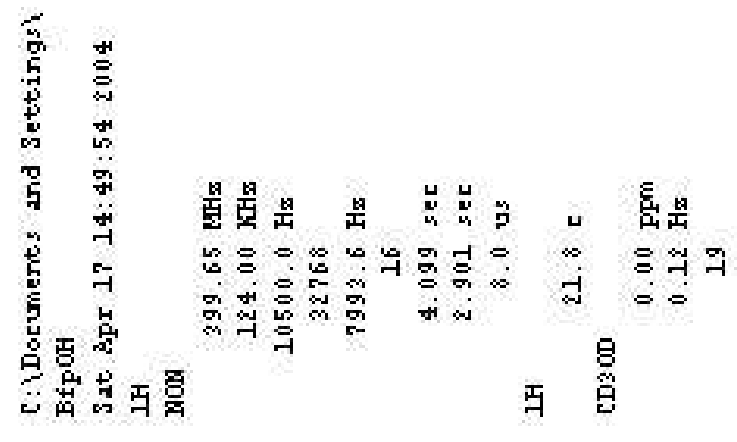

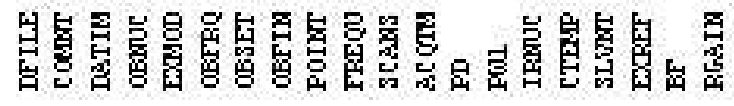
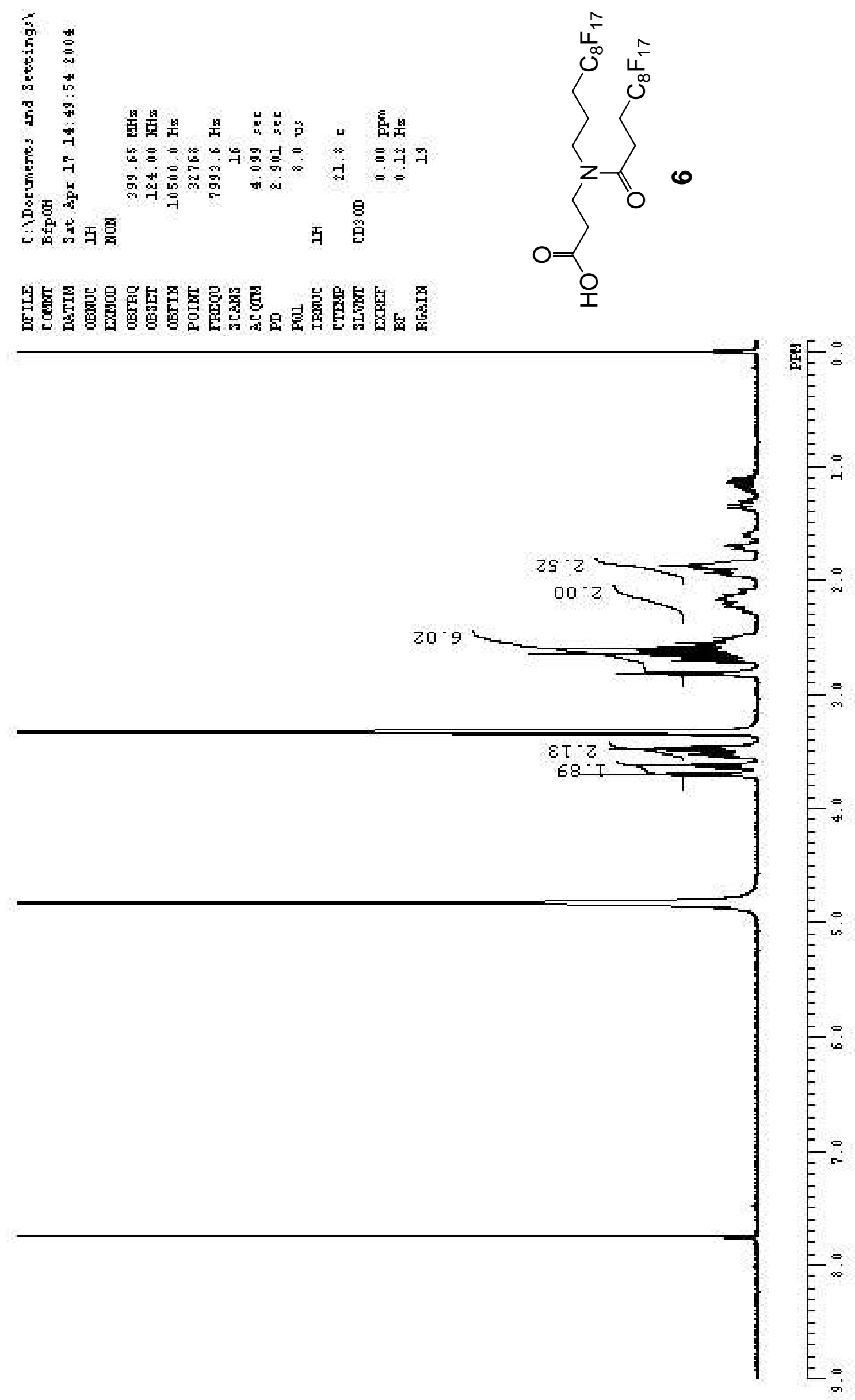


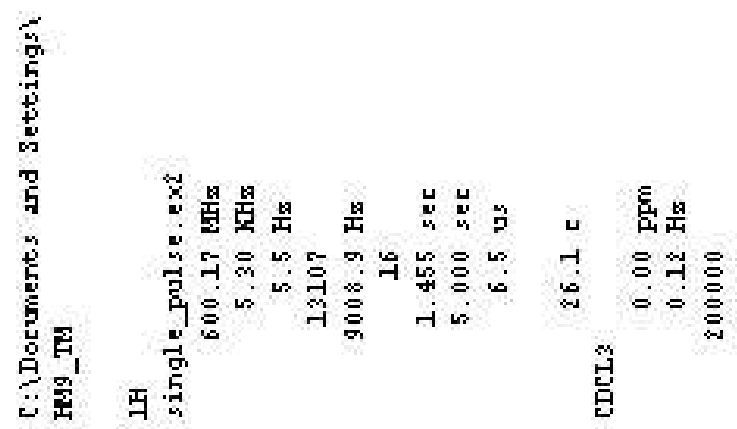

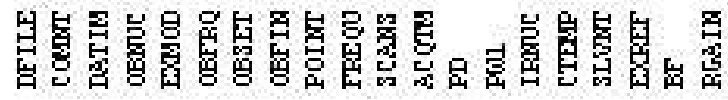

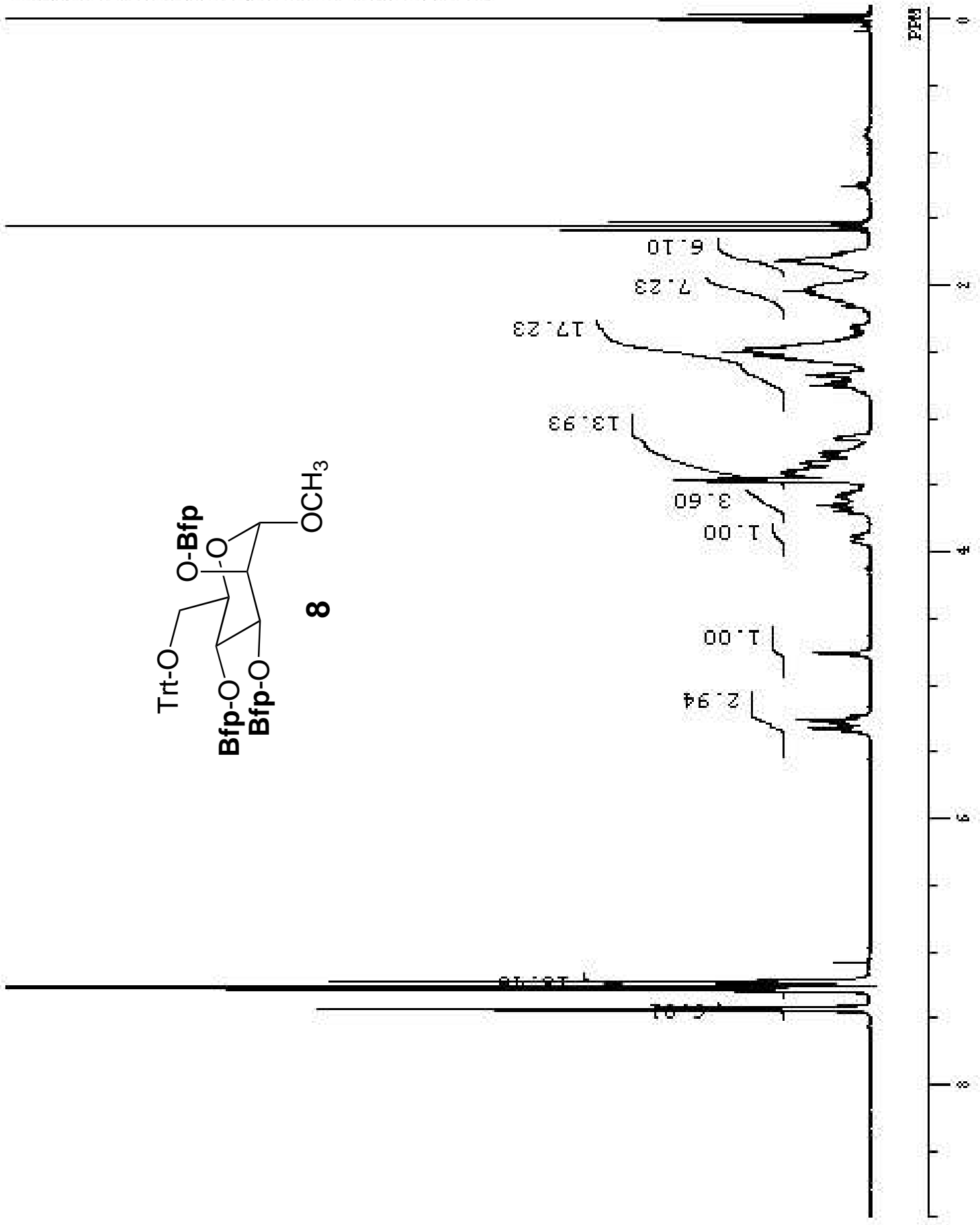




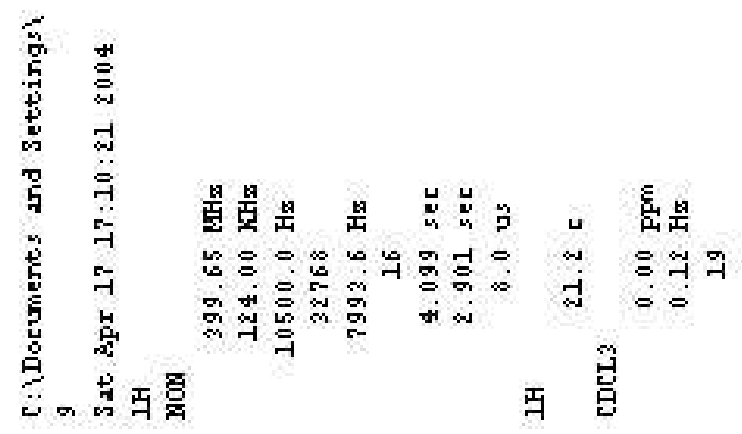

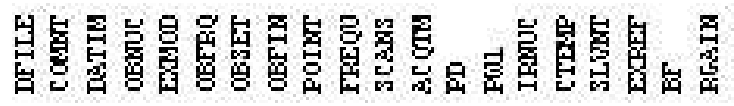

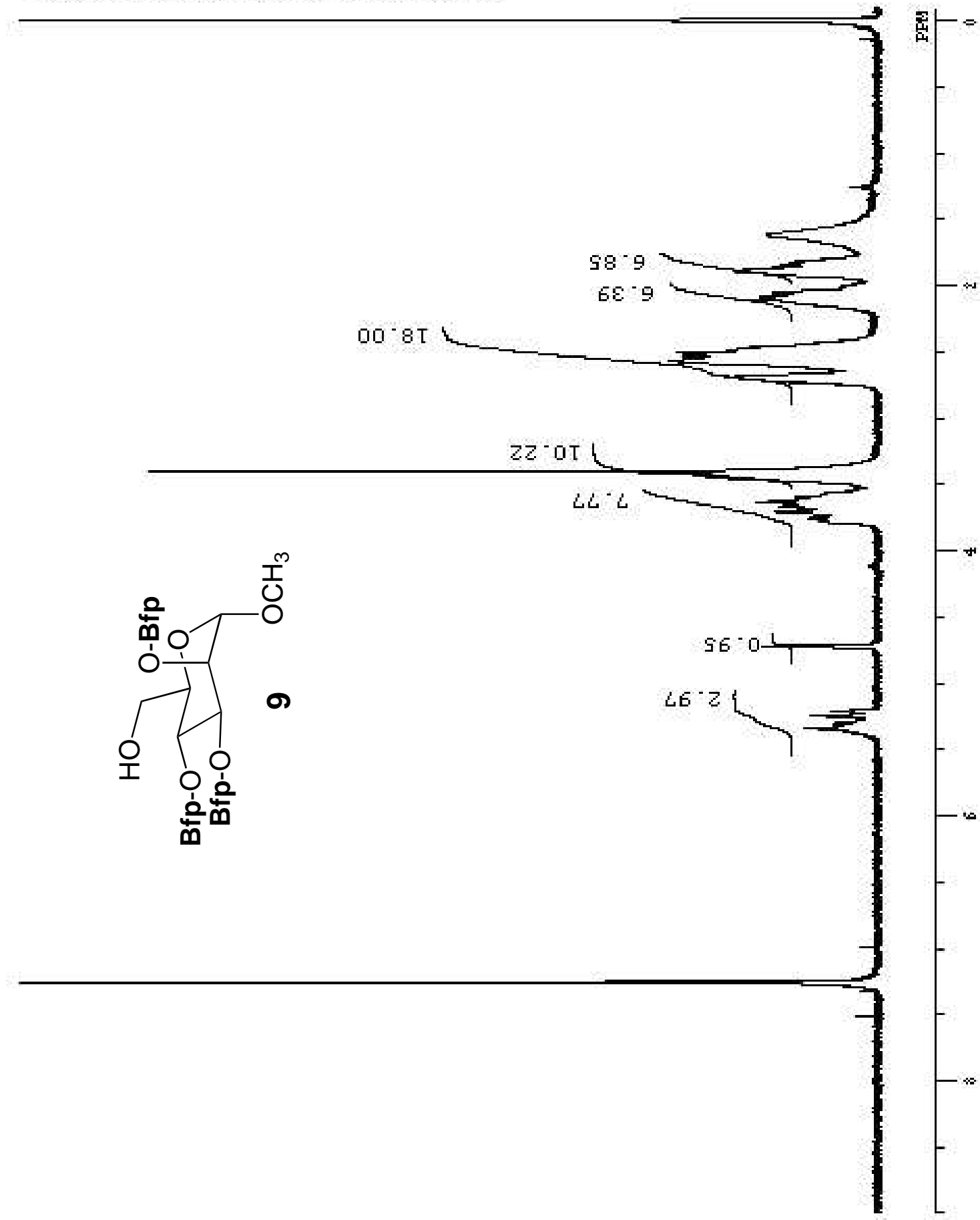




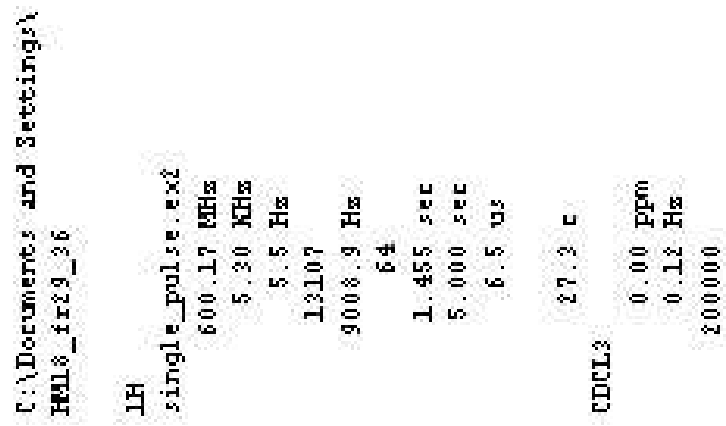

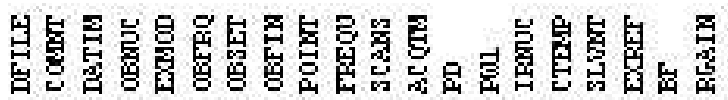

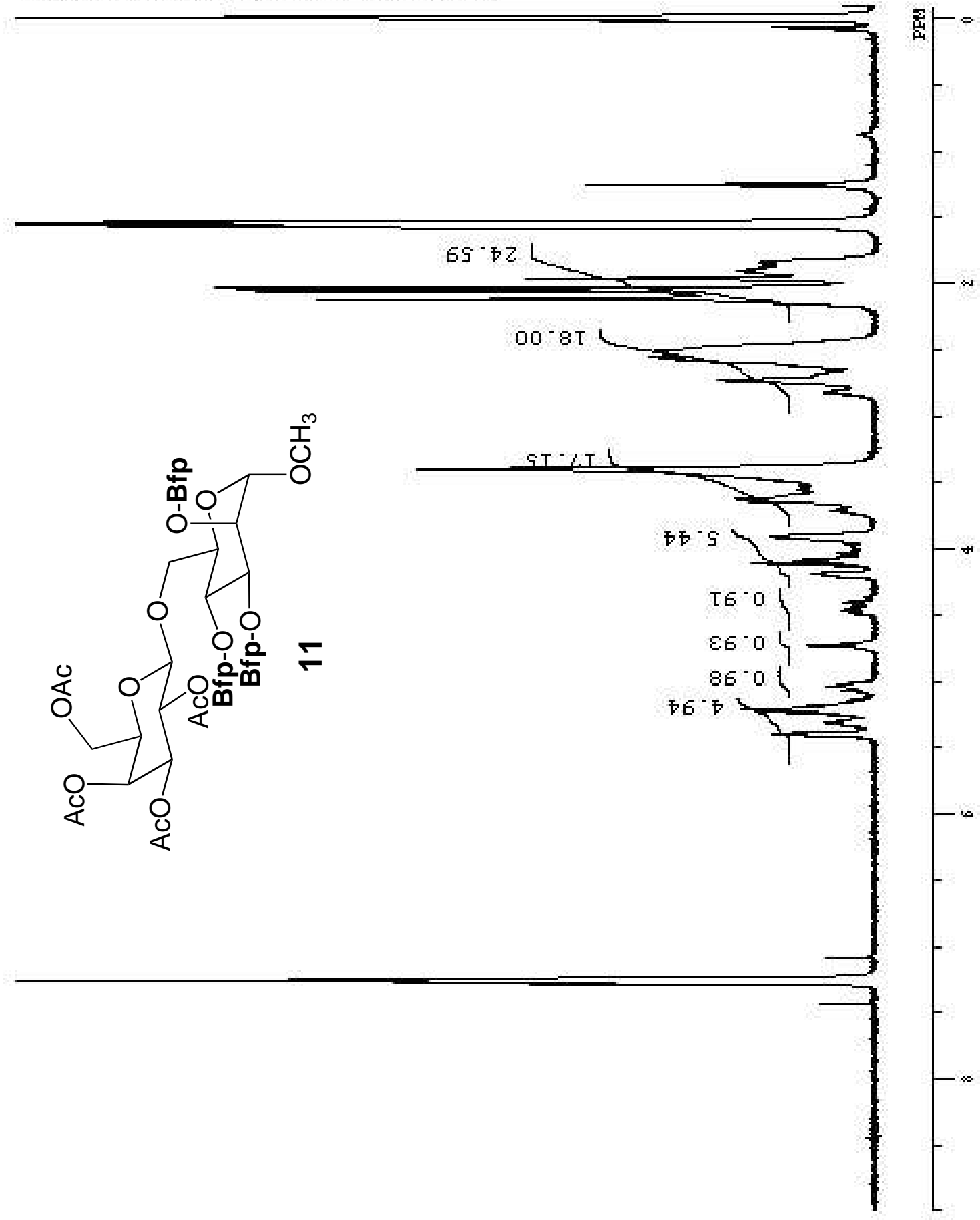




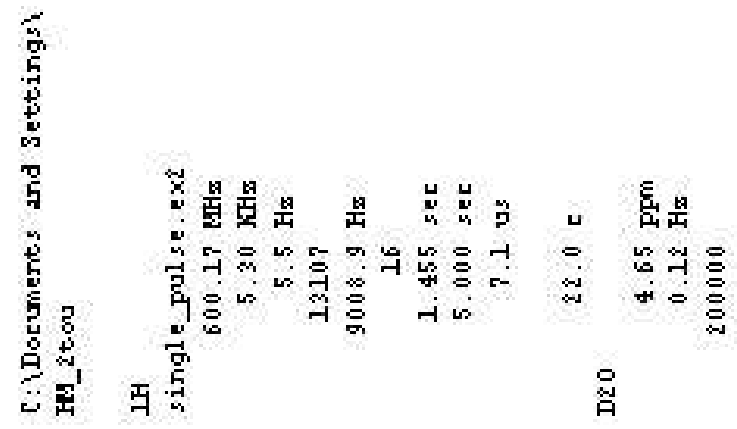

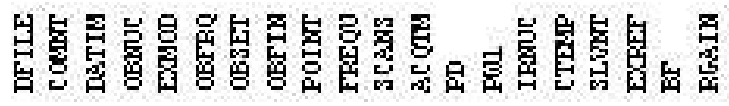

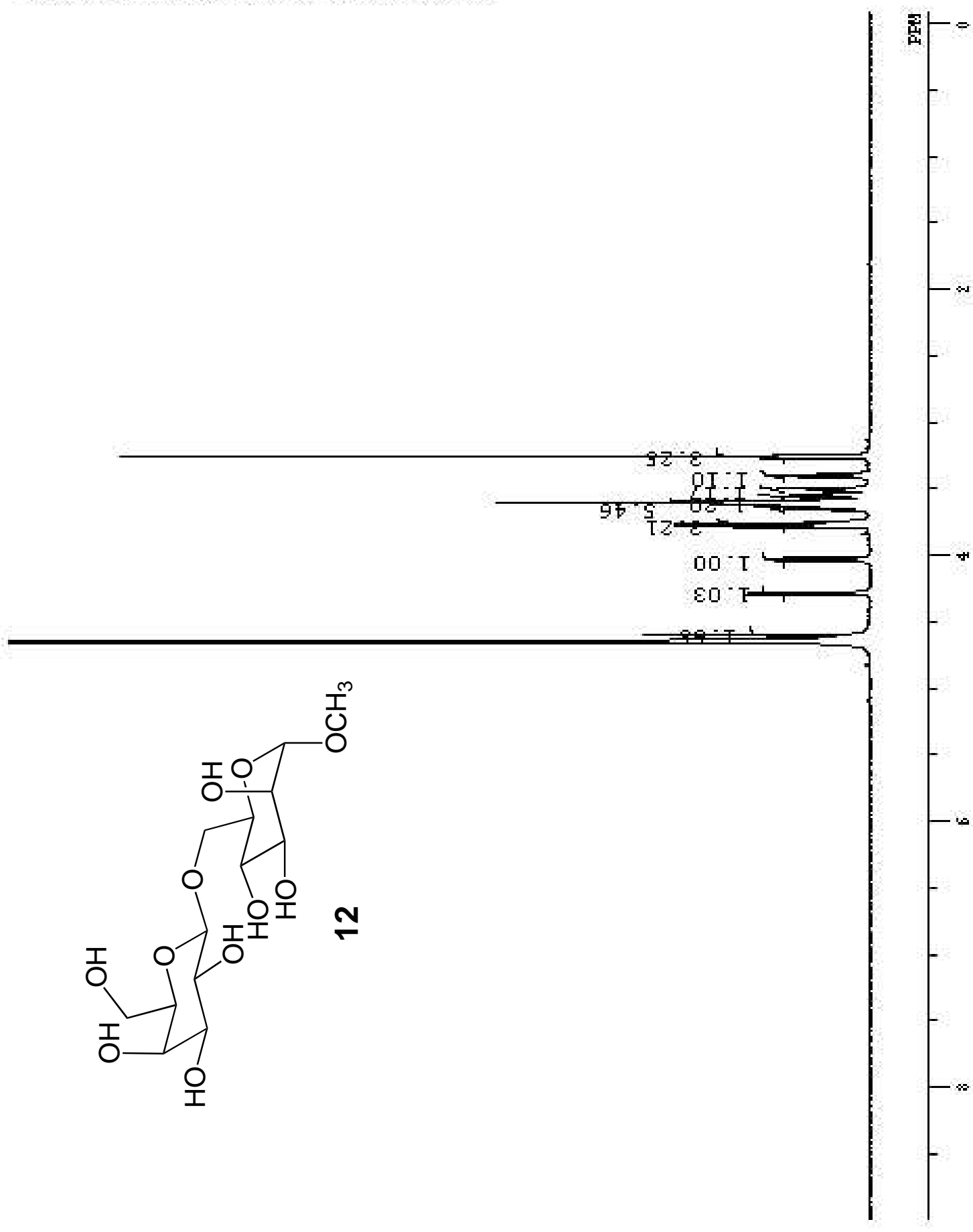




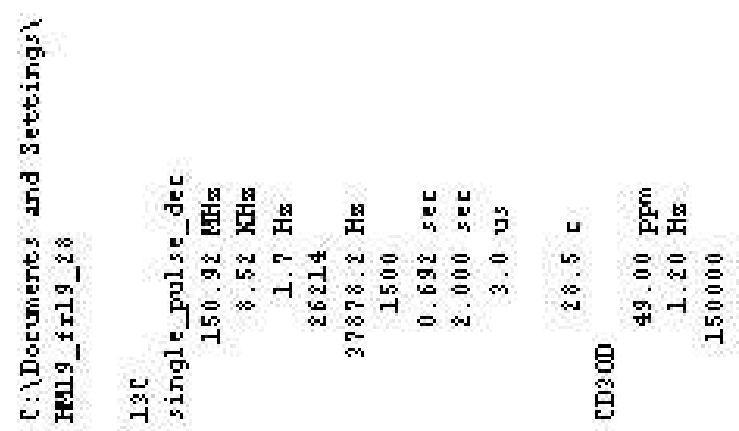

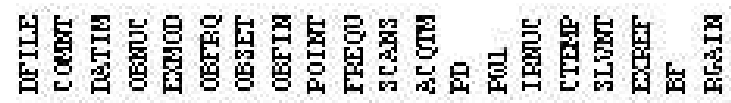

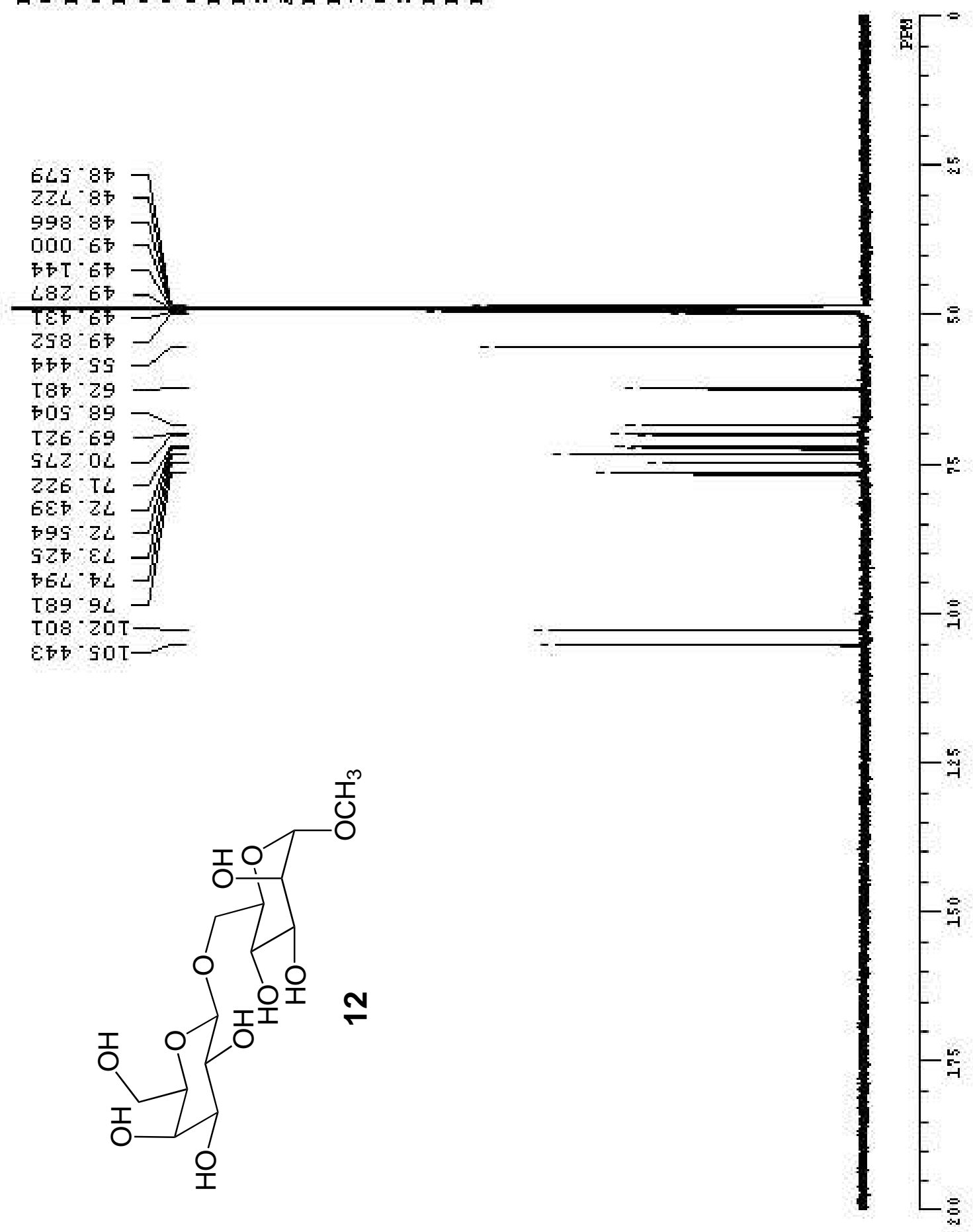




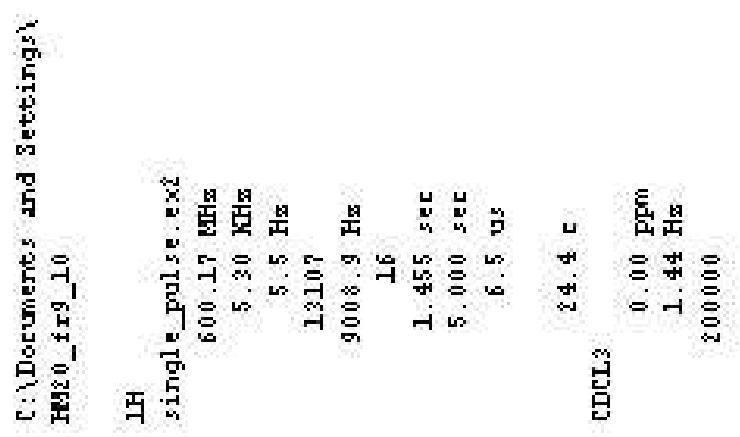

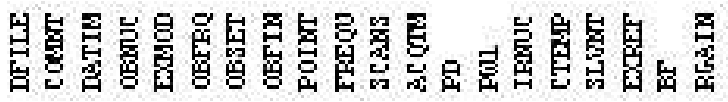

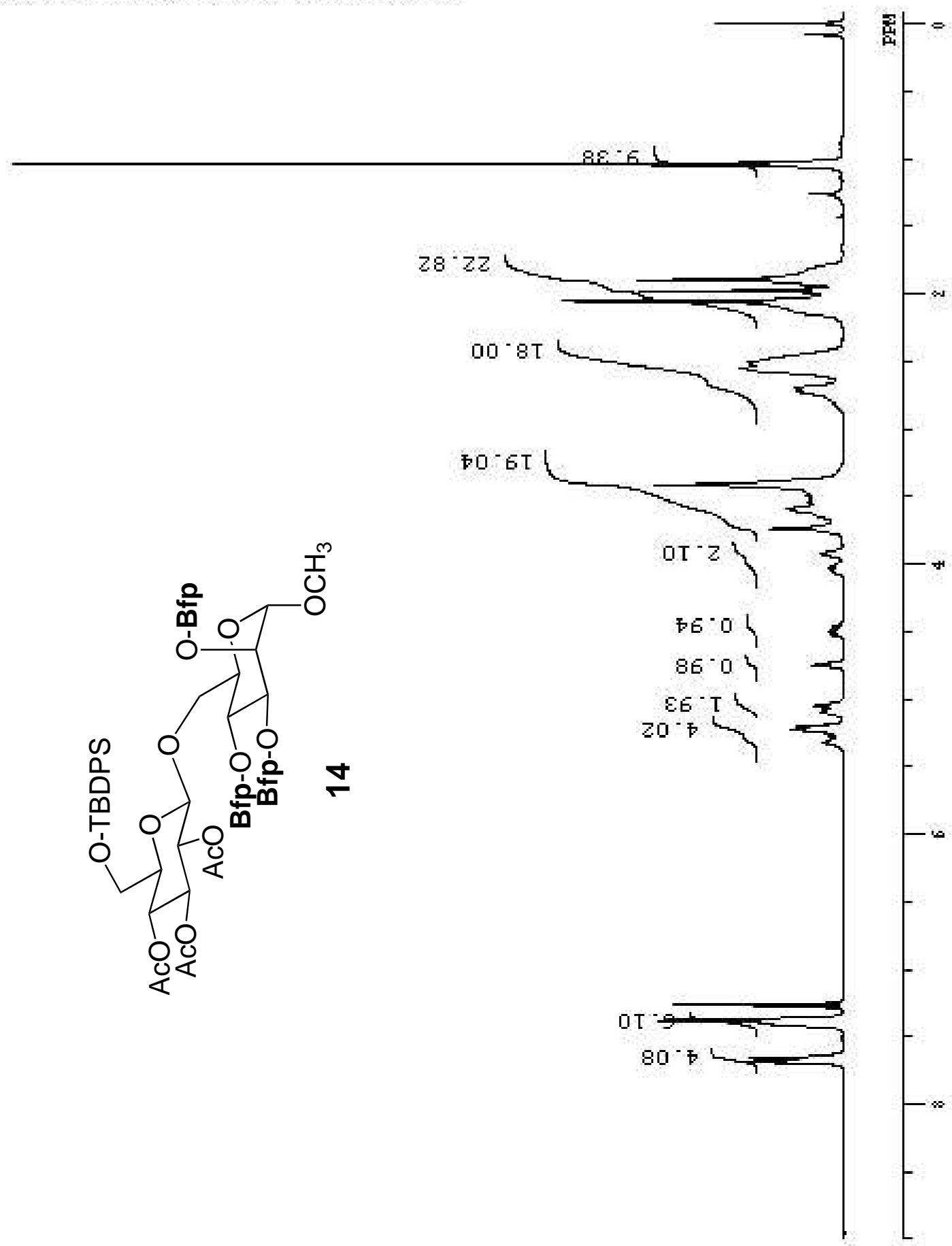




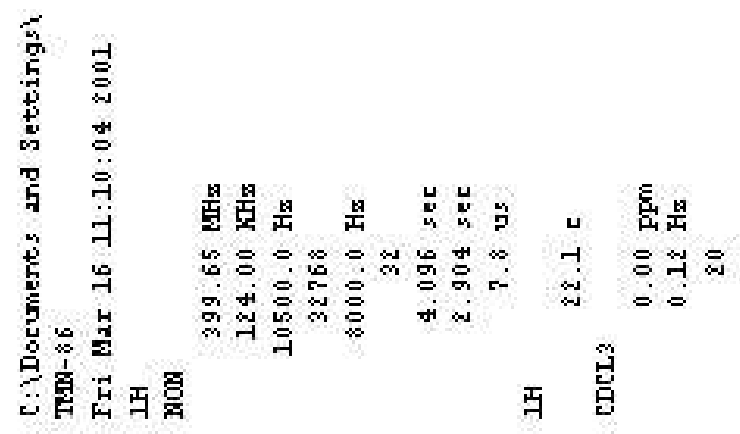

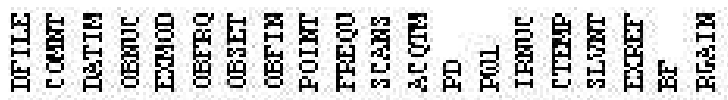

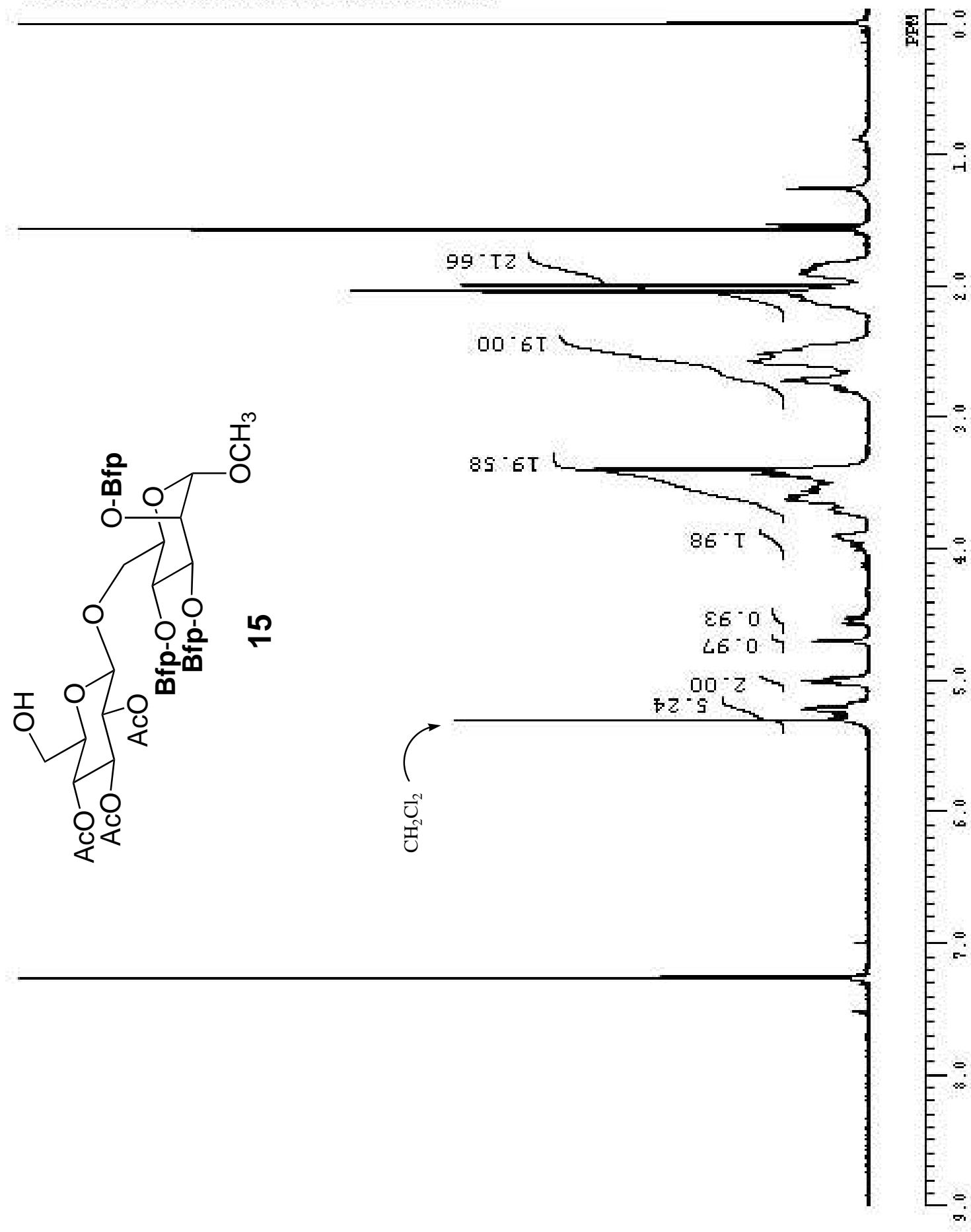




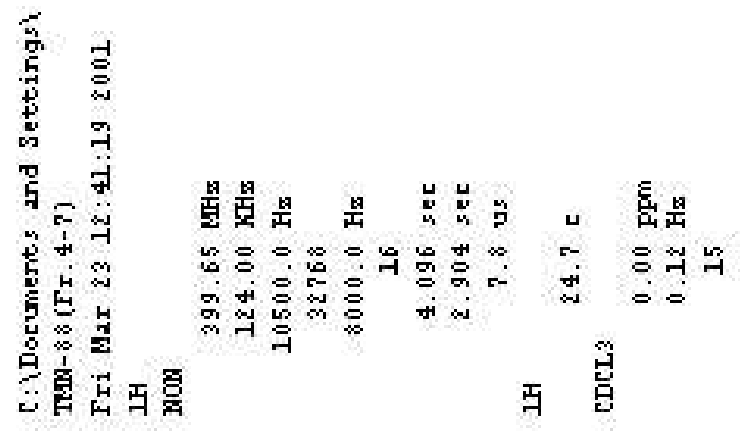

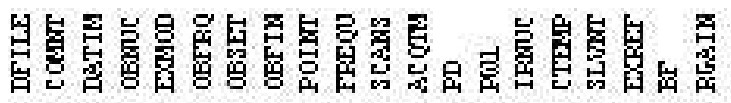
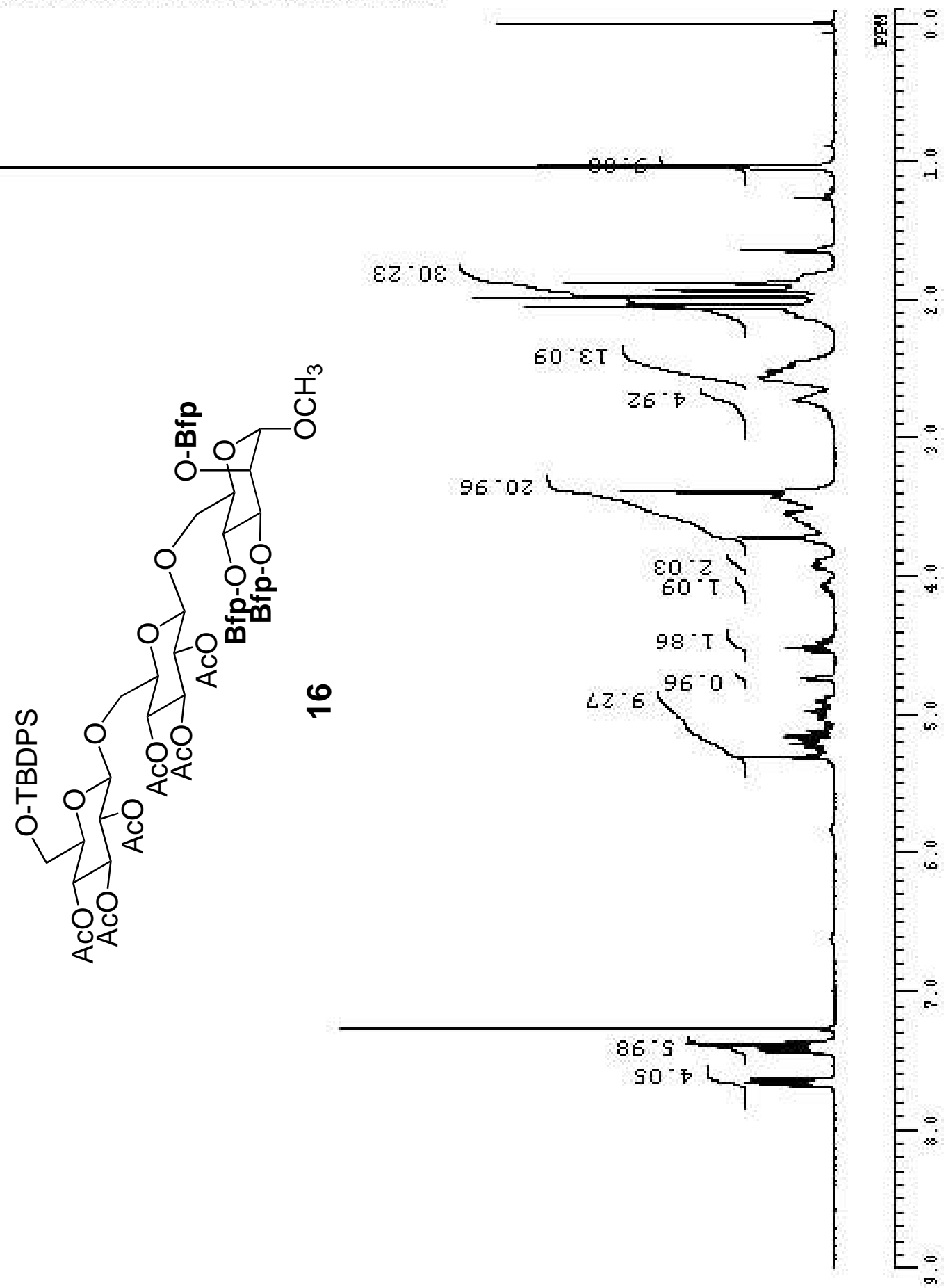


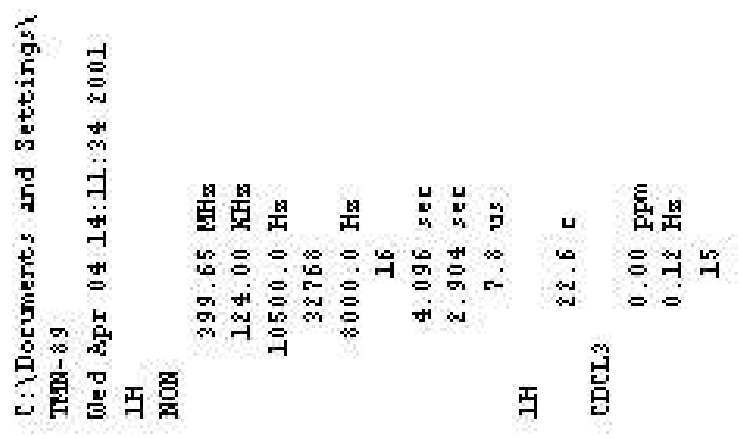

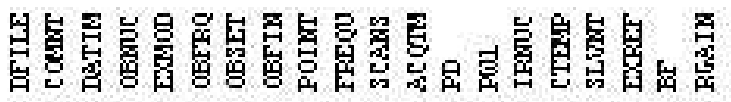

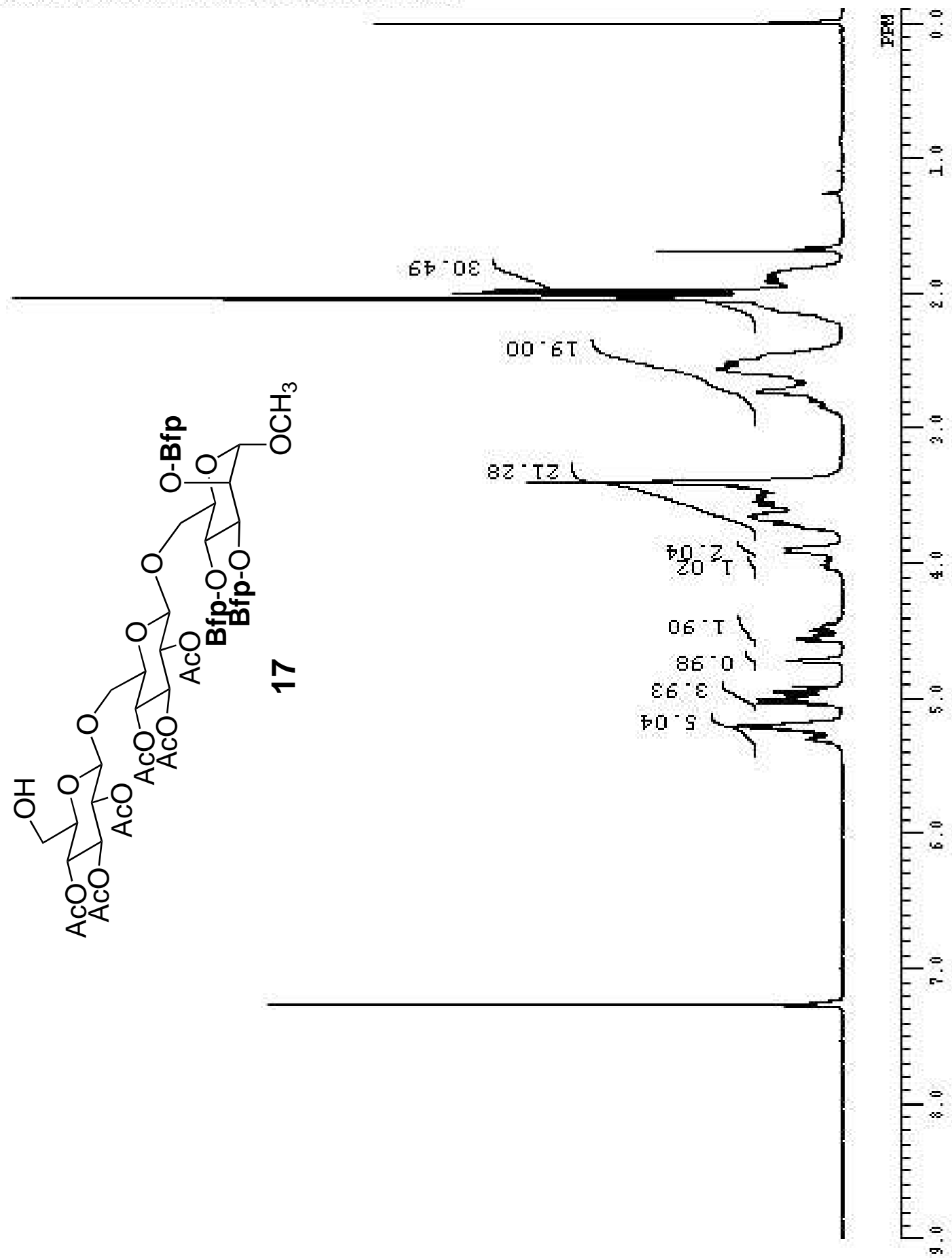




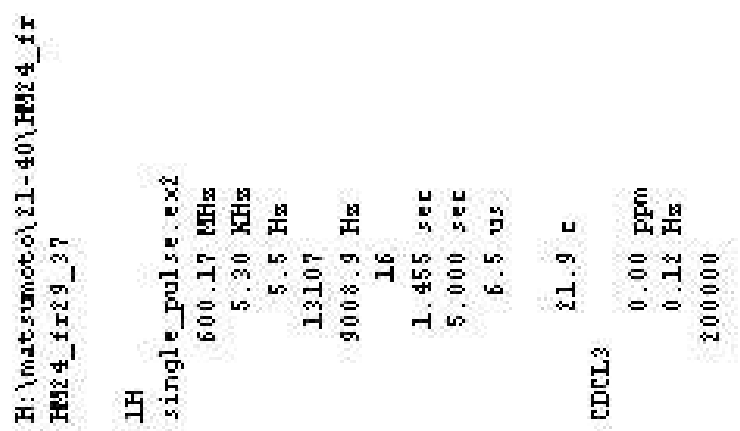

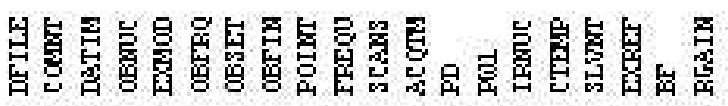

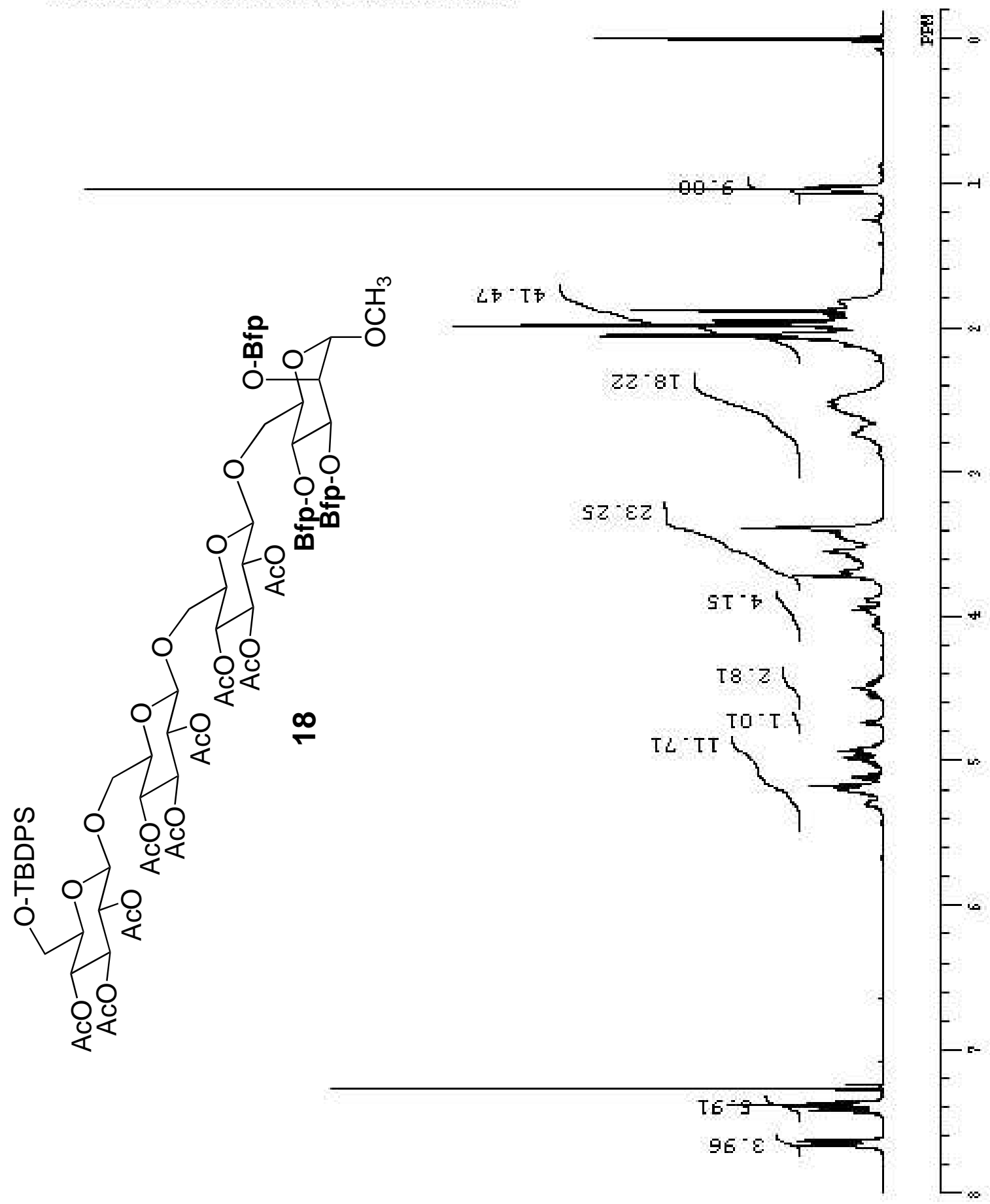




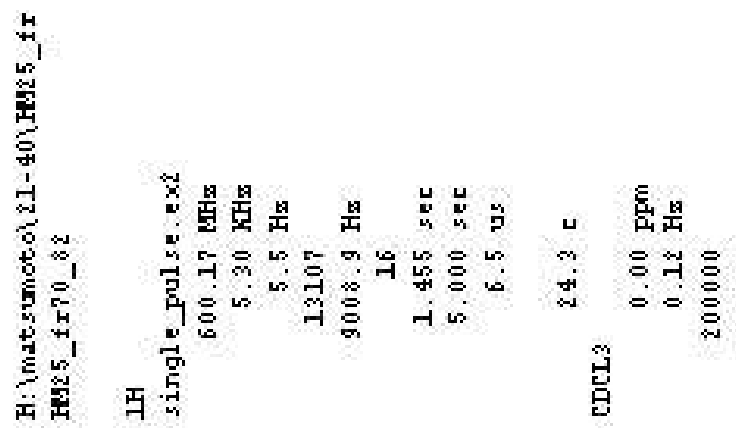

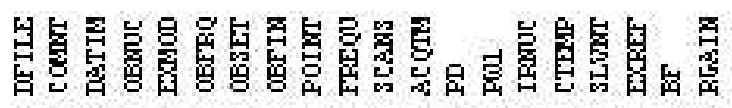

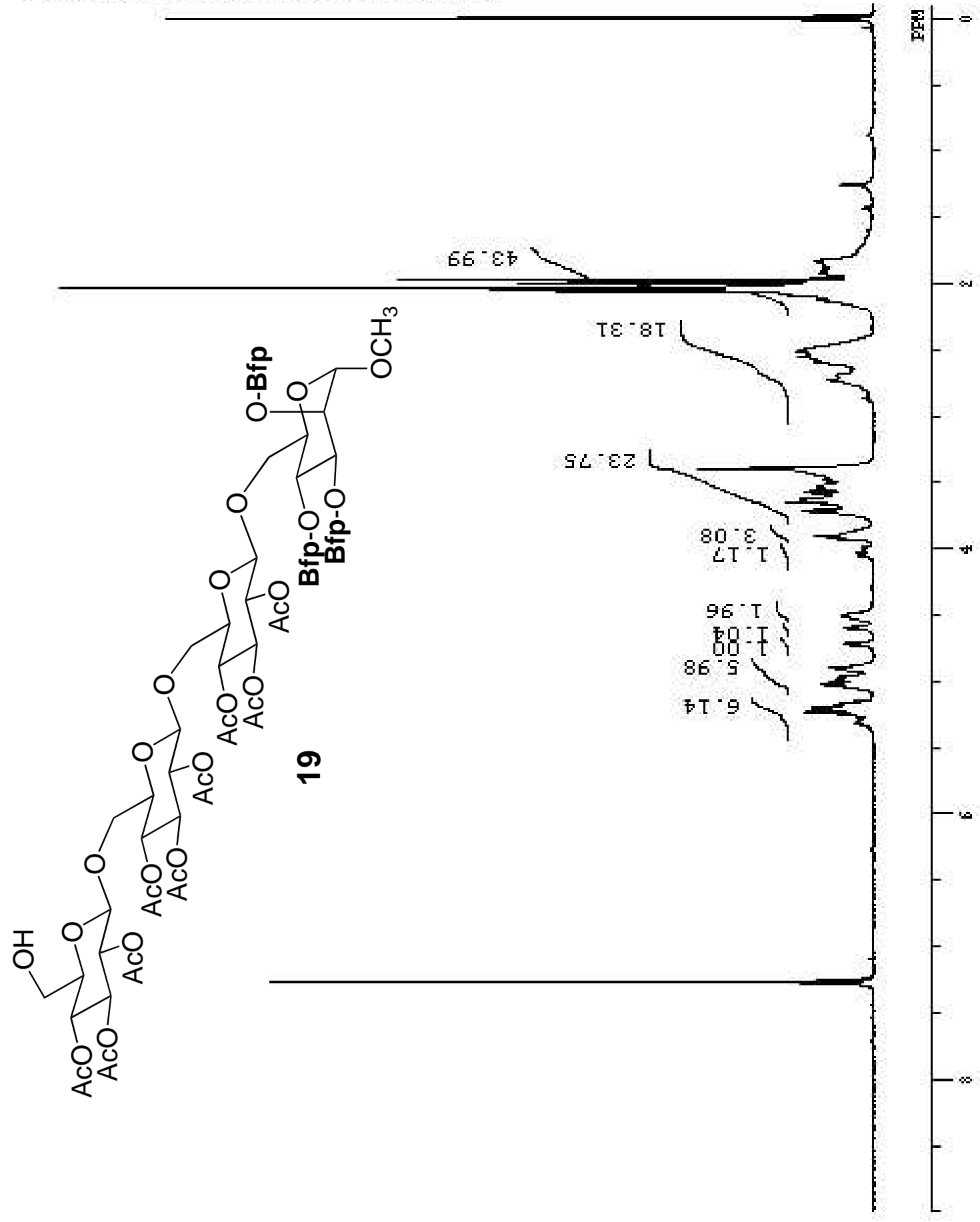




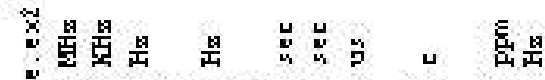

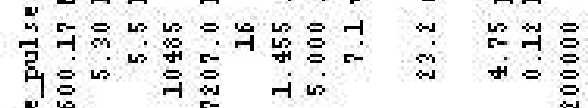

西宾

晧

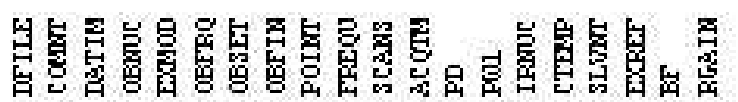
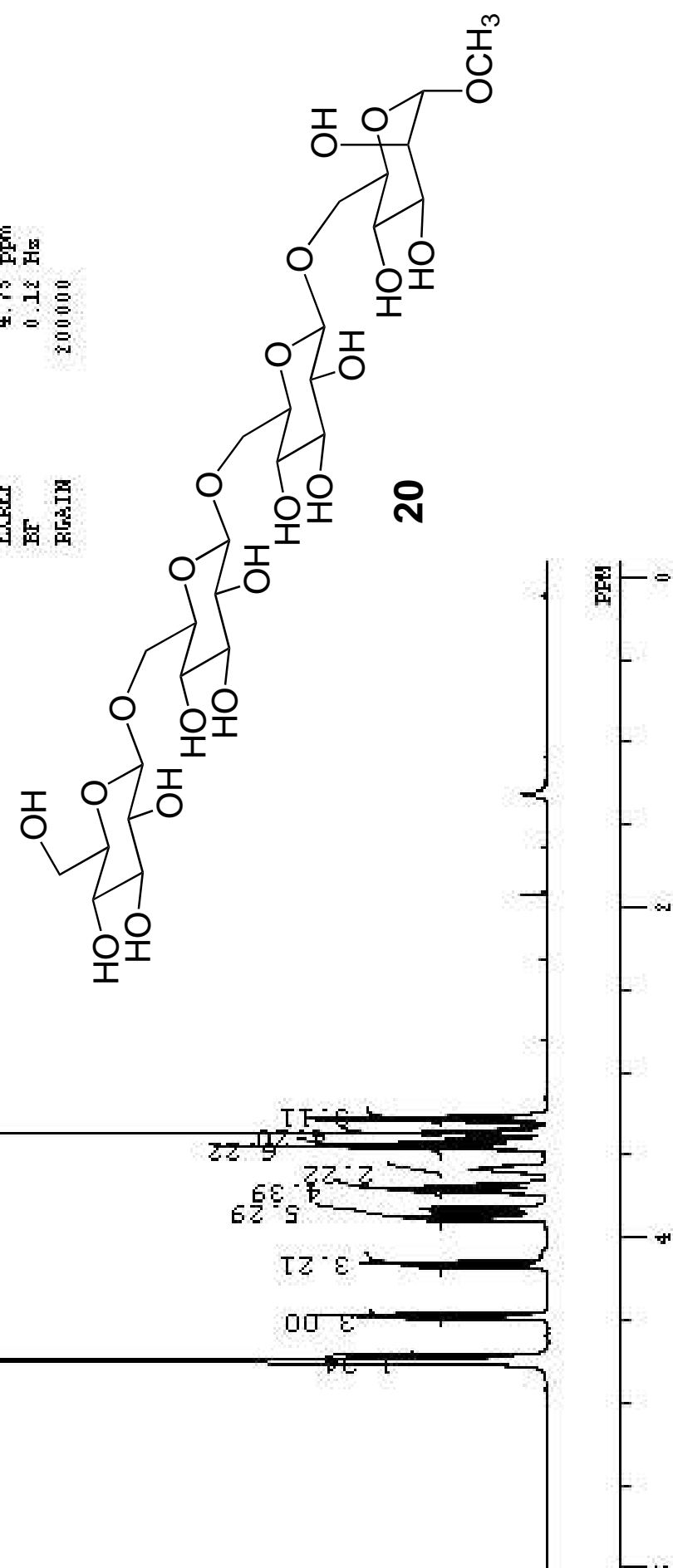


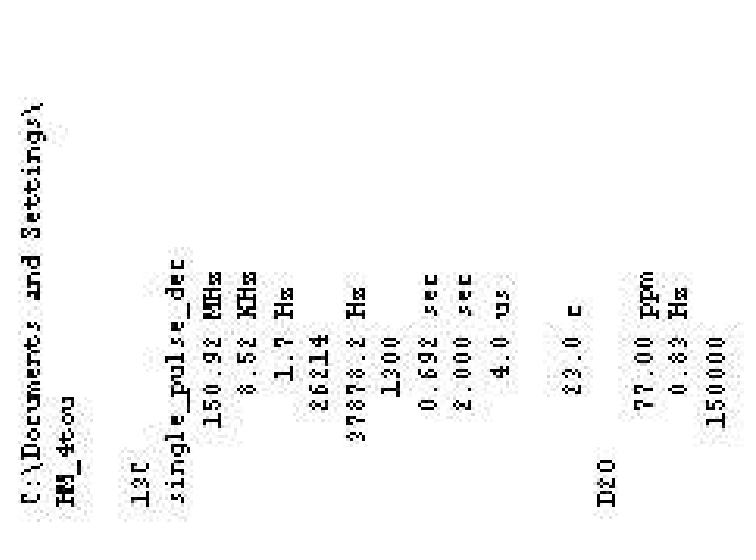

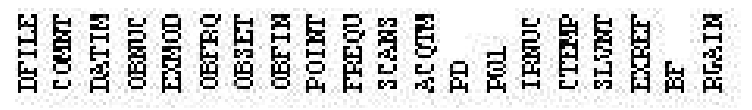
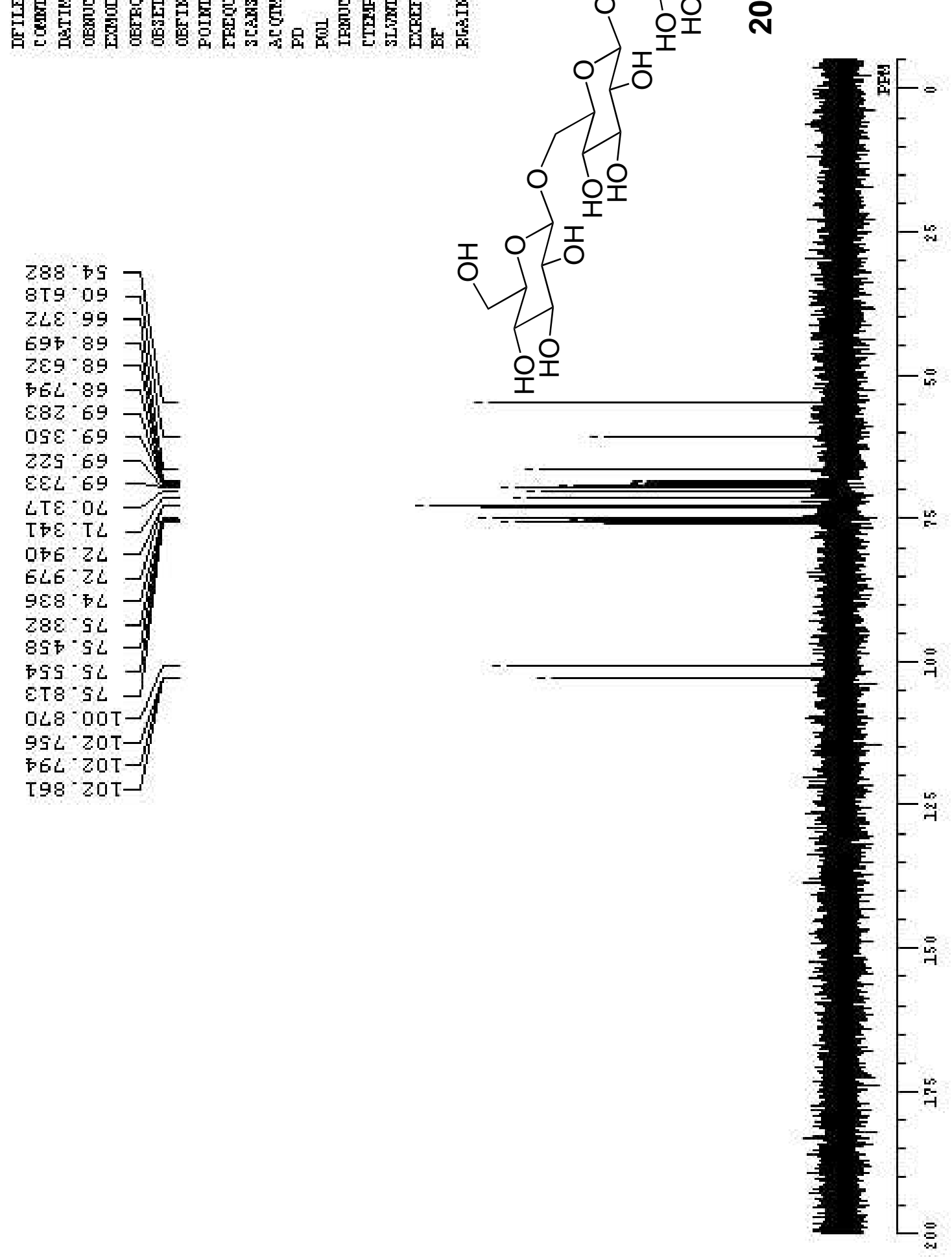


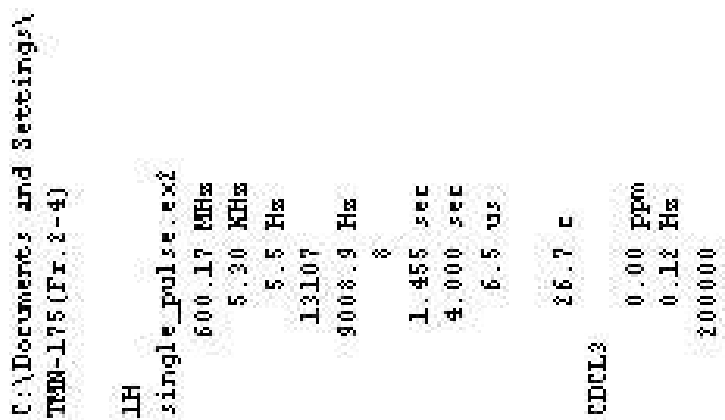

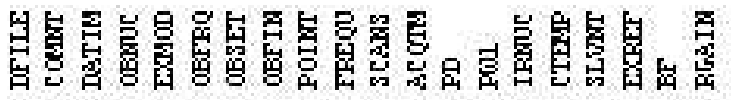

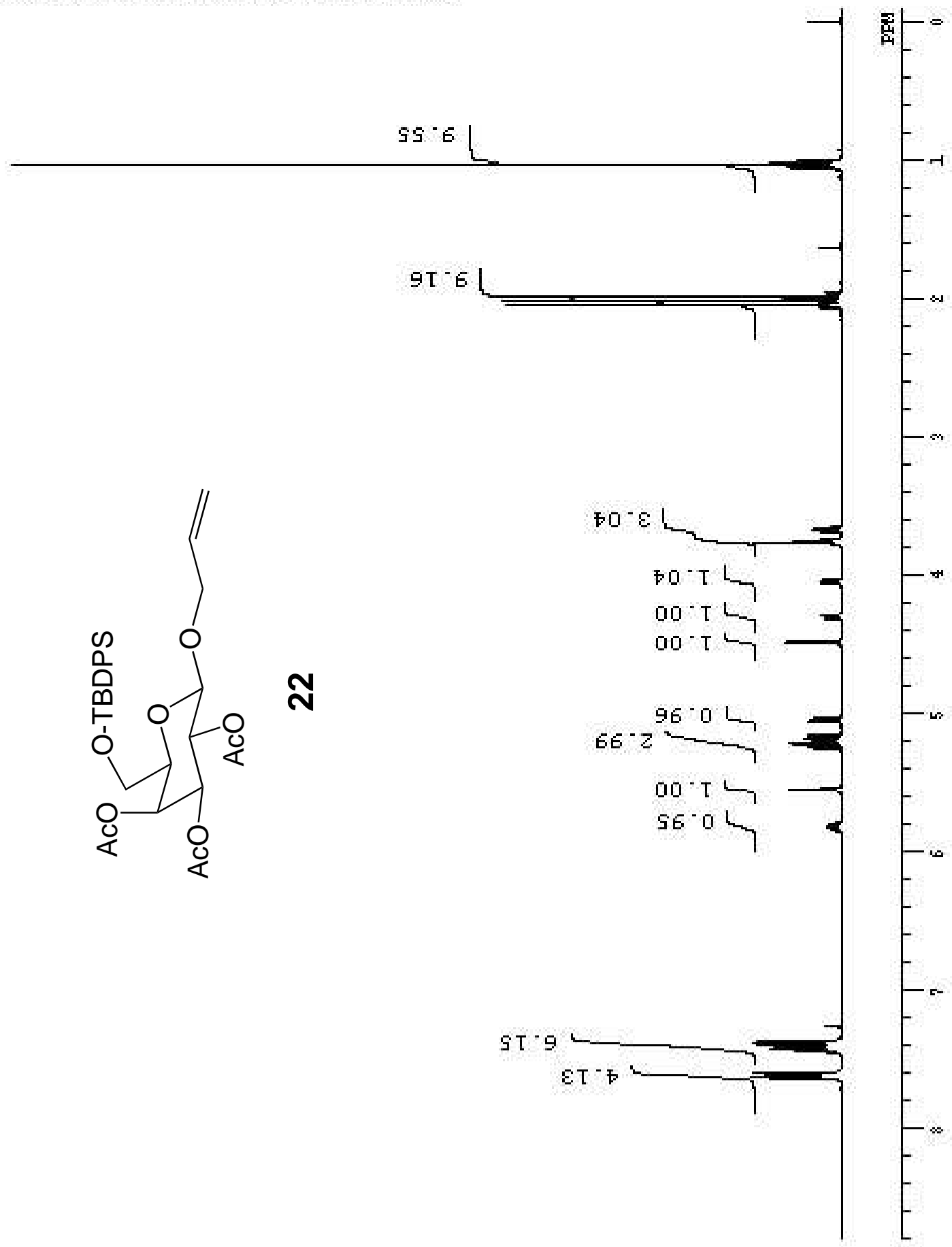




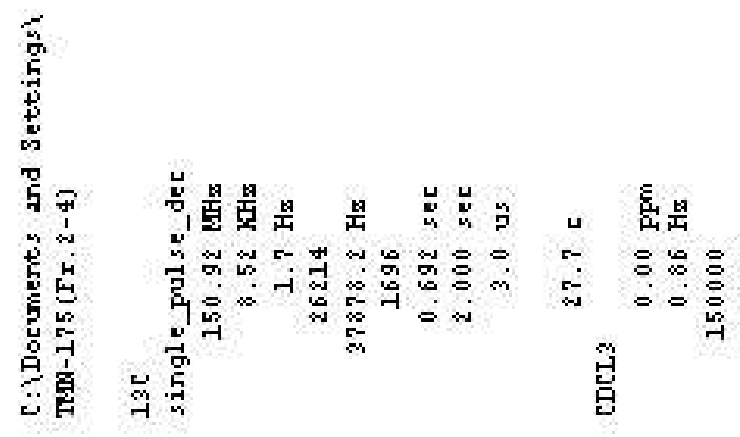

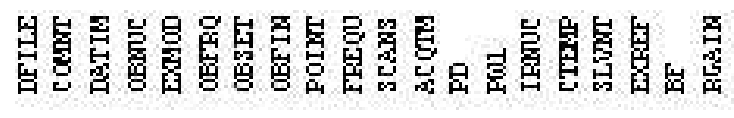
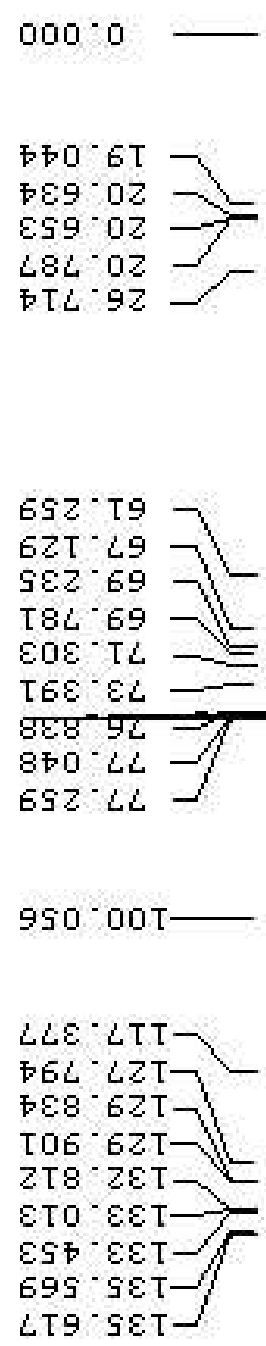

$887^{\circ} 69 \mathrm{~T}$

STT OLT

TTZ $0 L \mathrm{~T}$

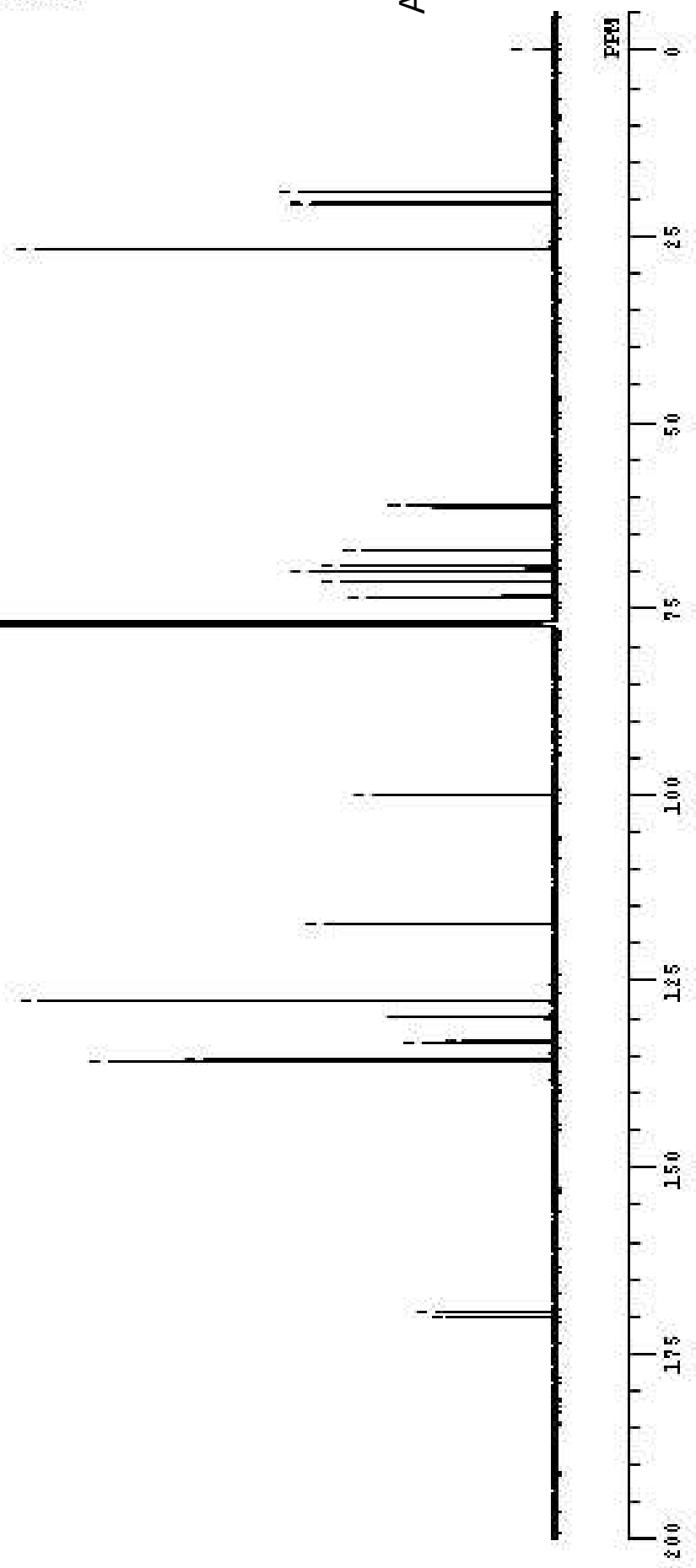




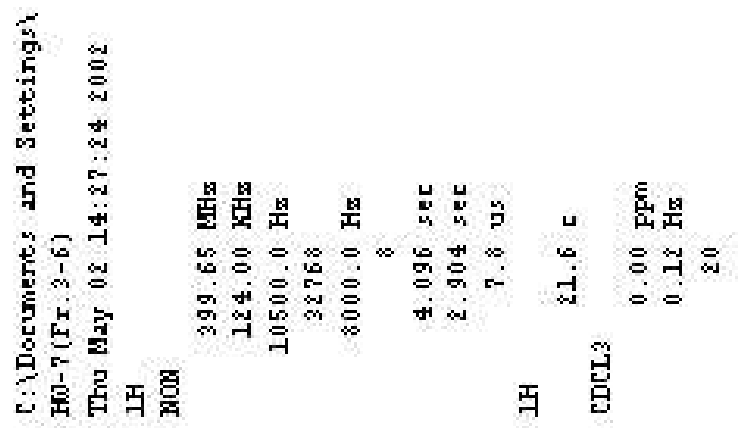

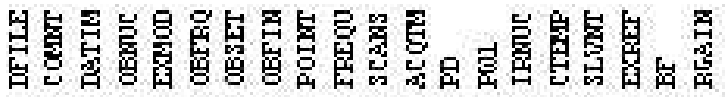

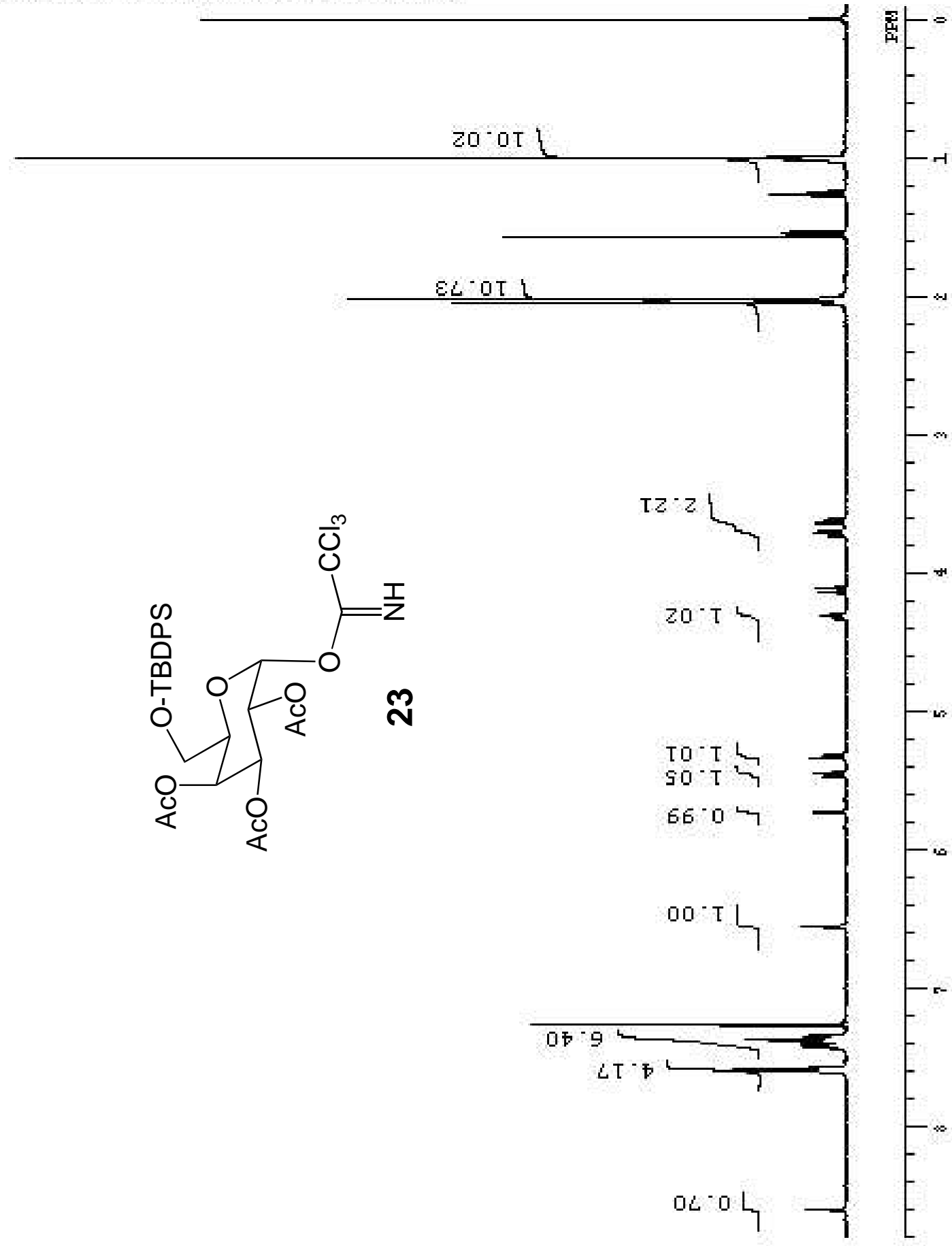




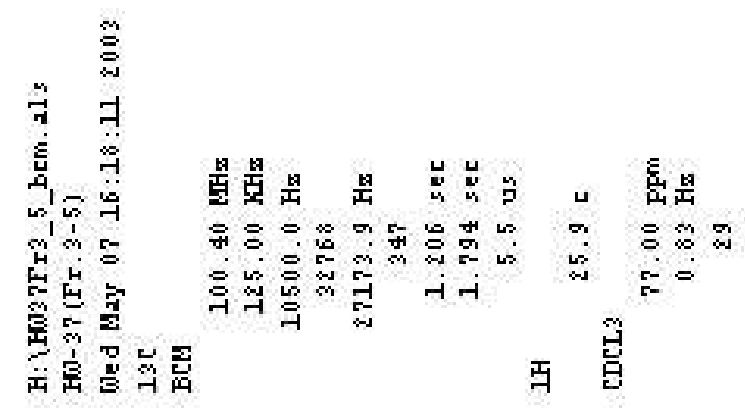

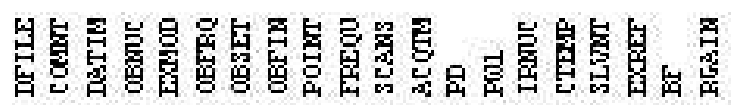
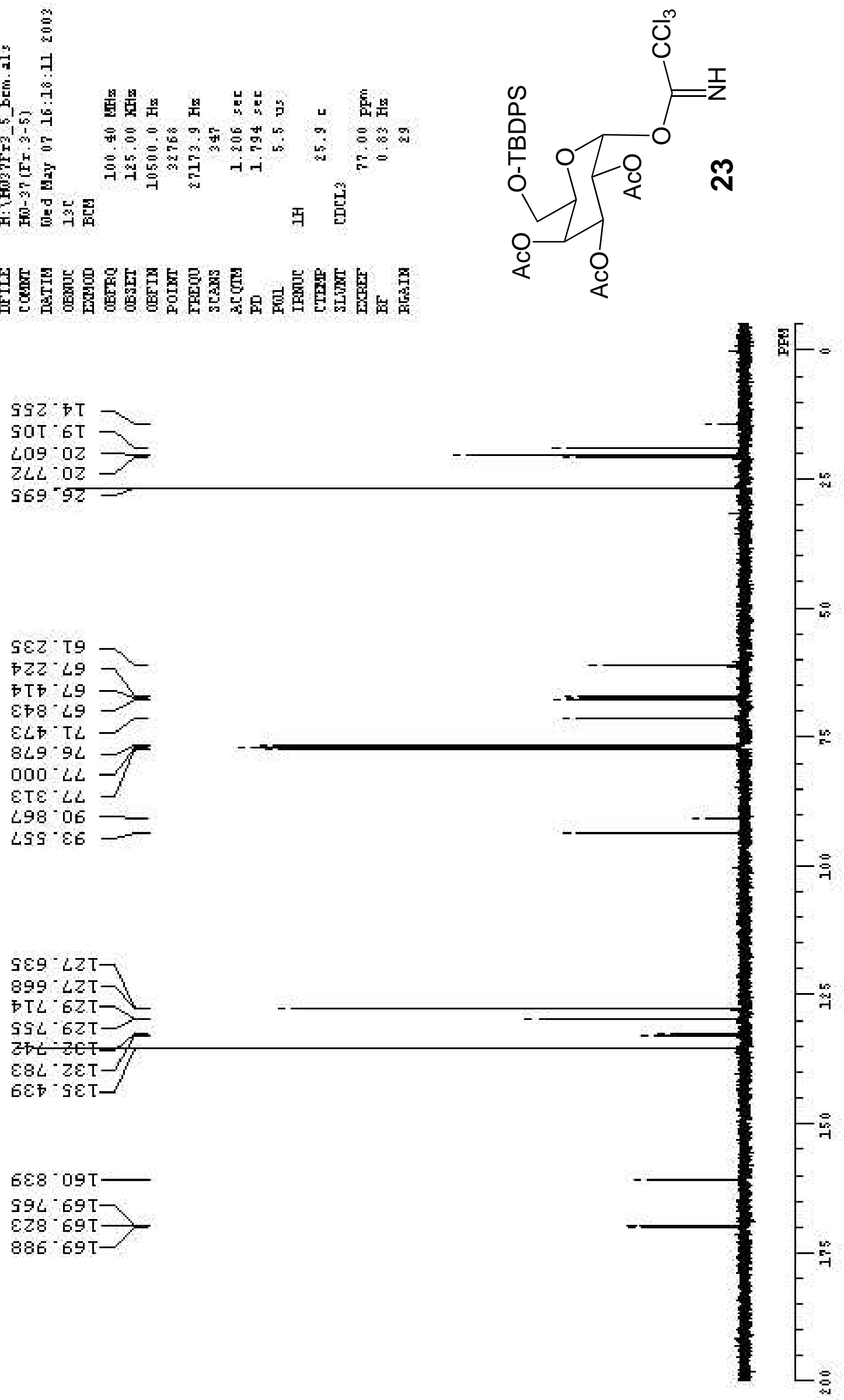


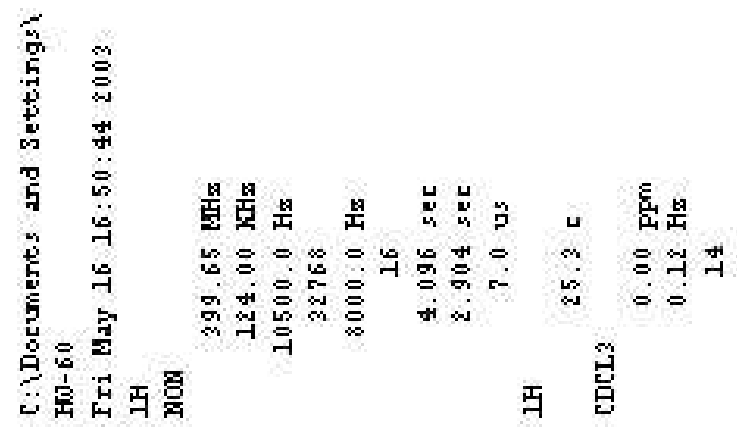

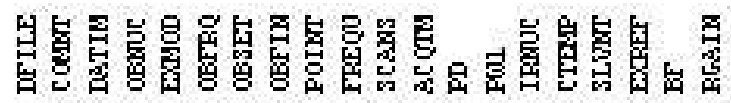
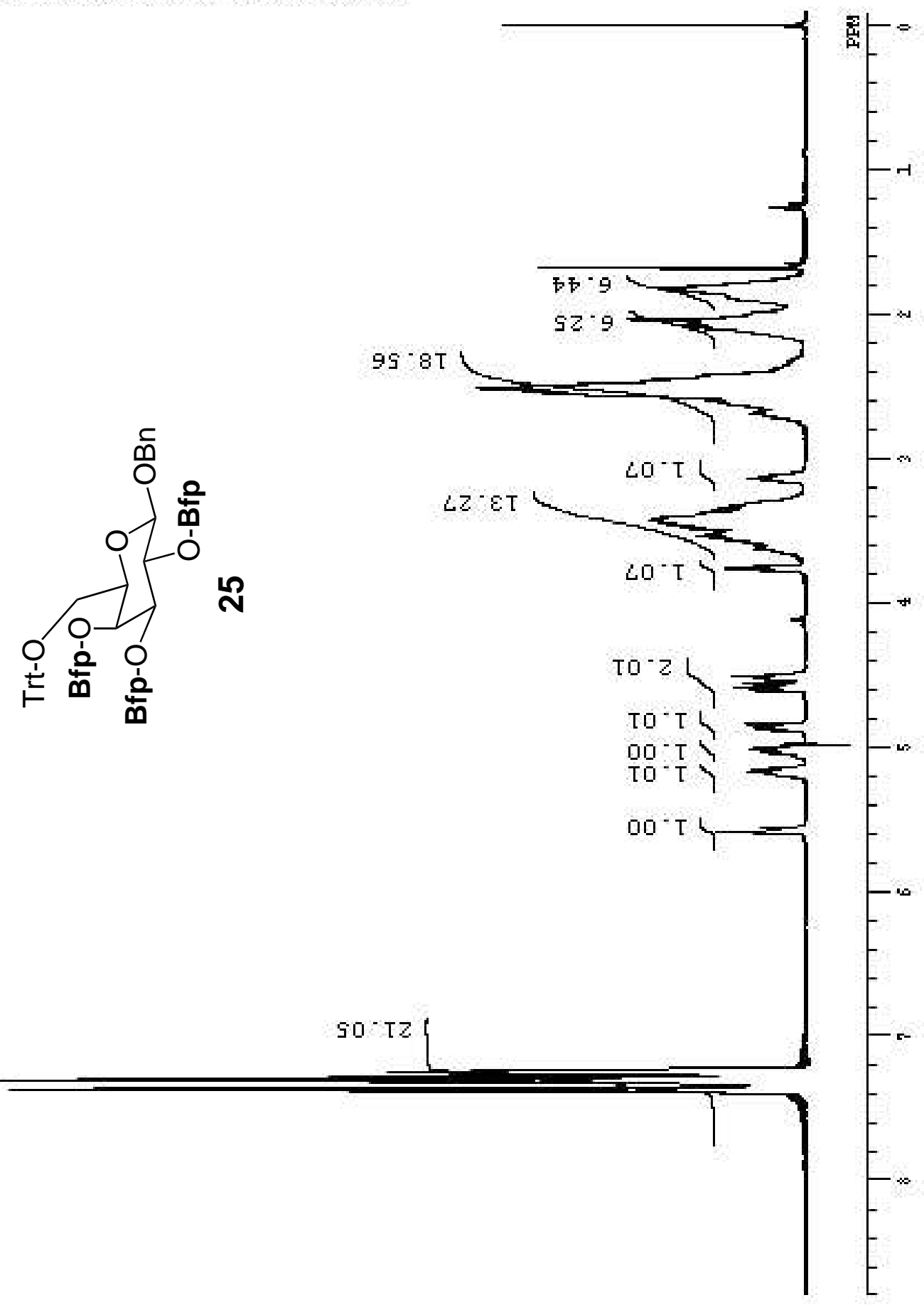


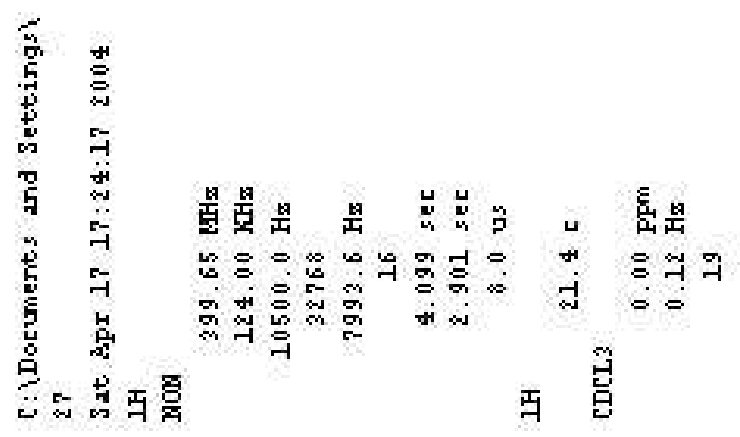

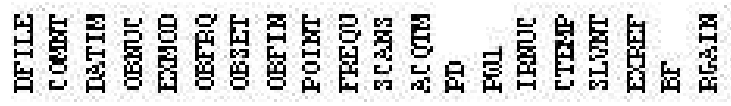

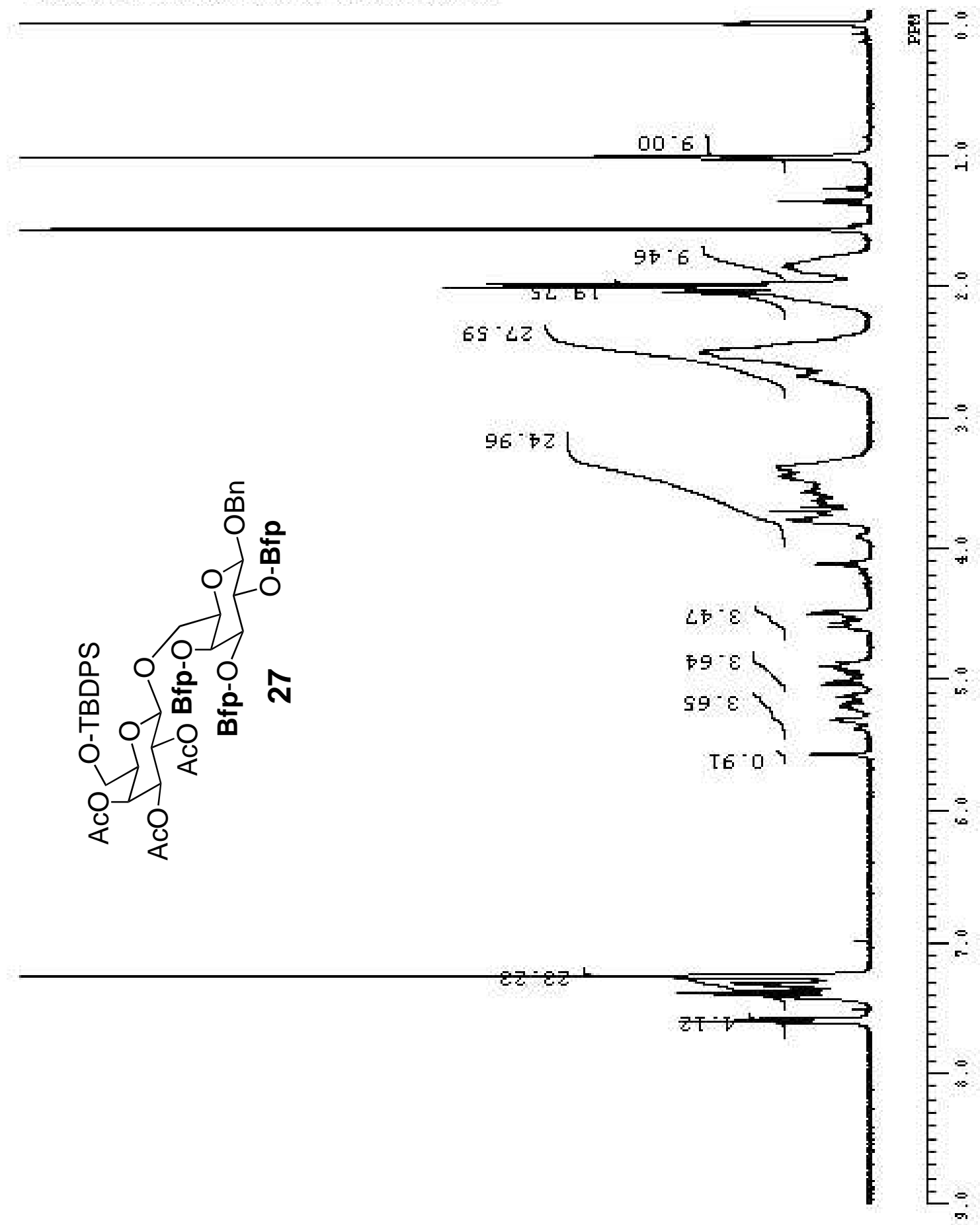




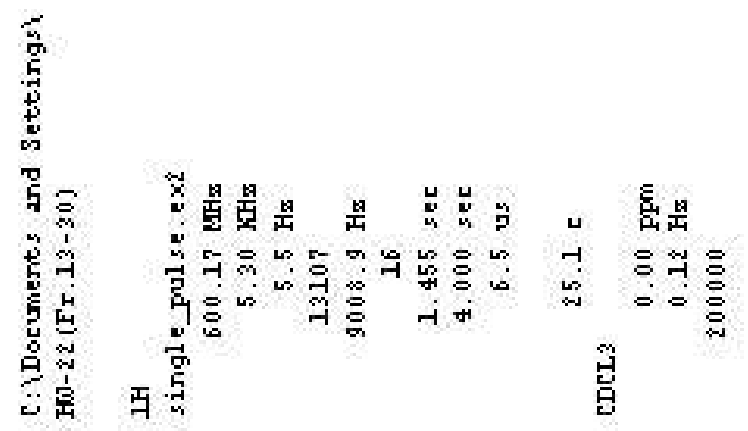

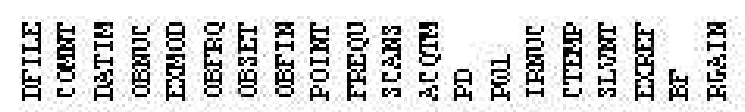

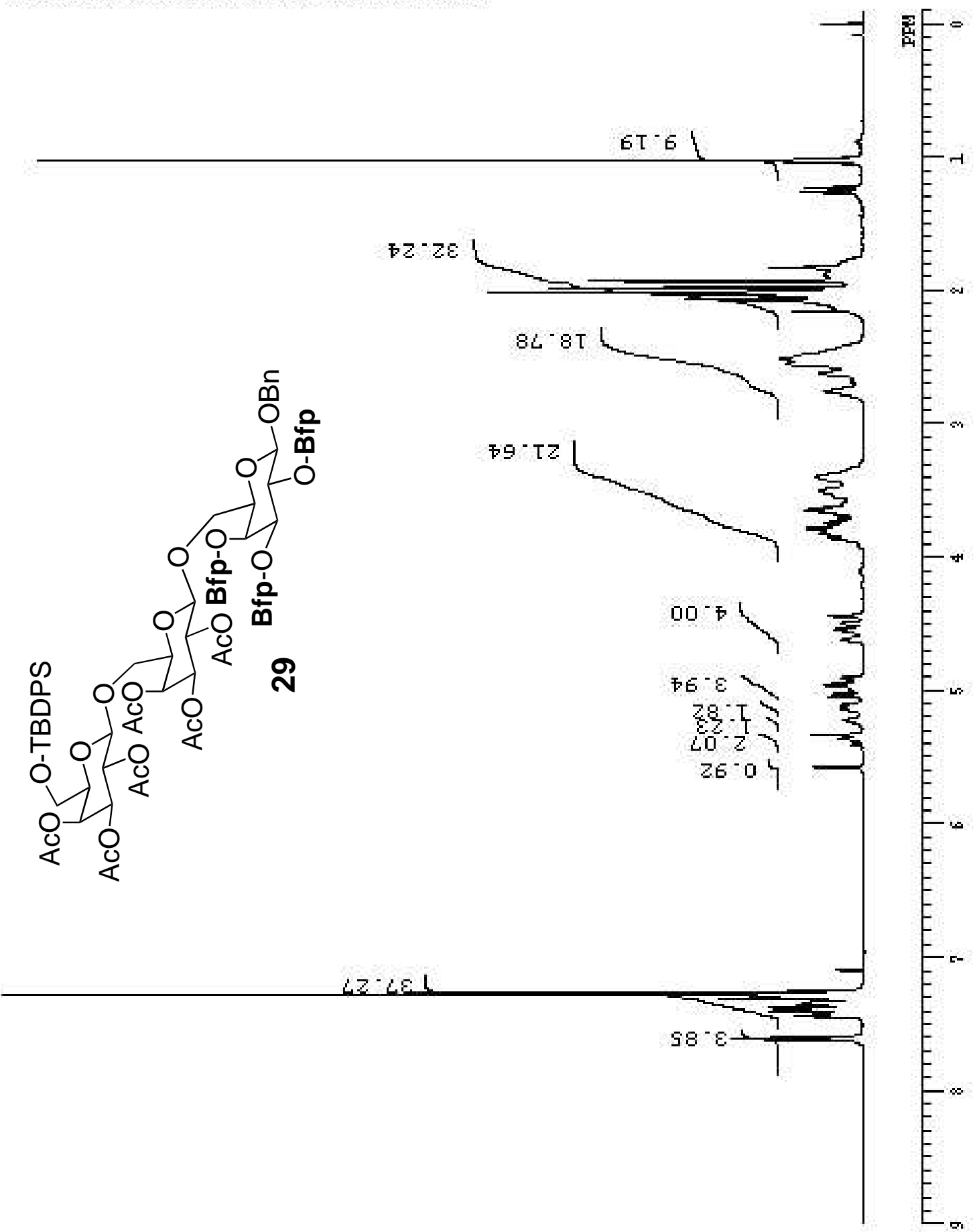




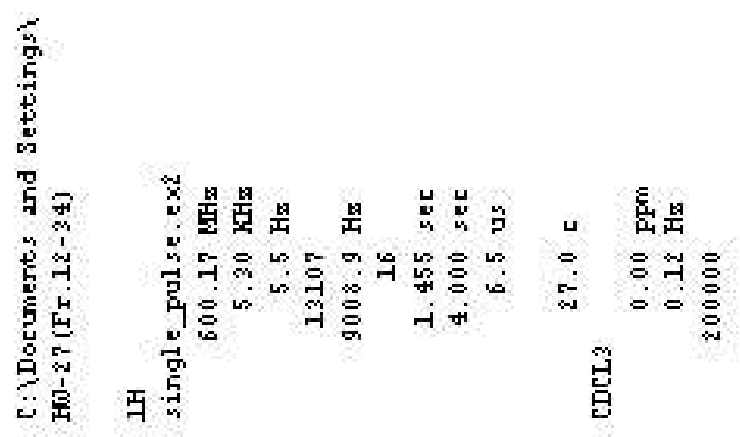

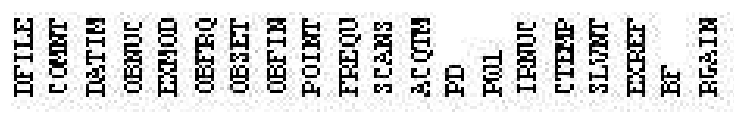
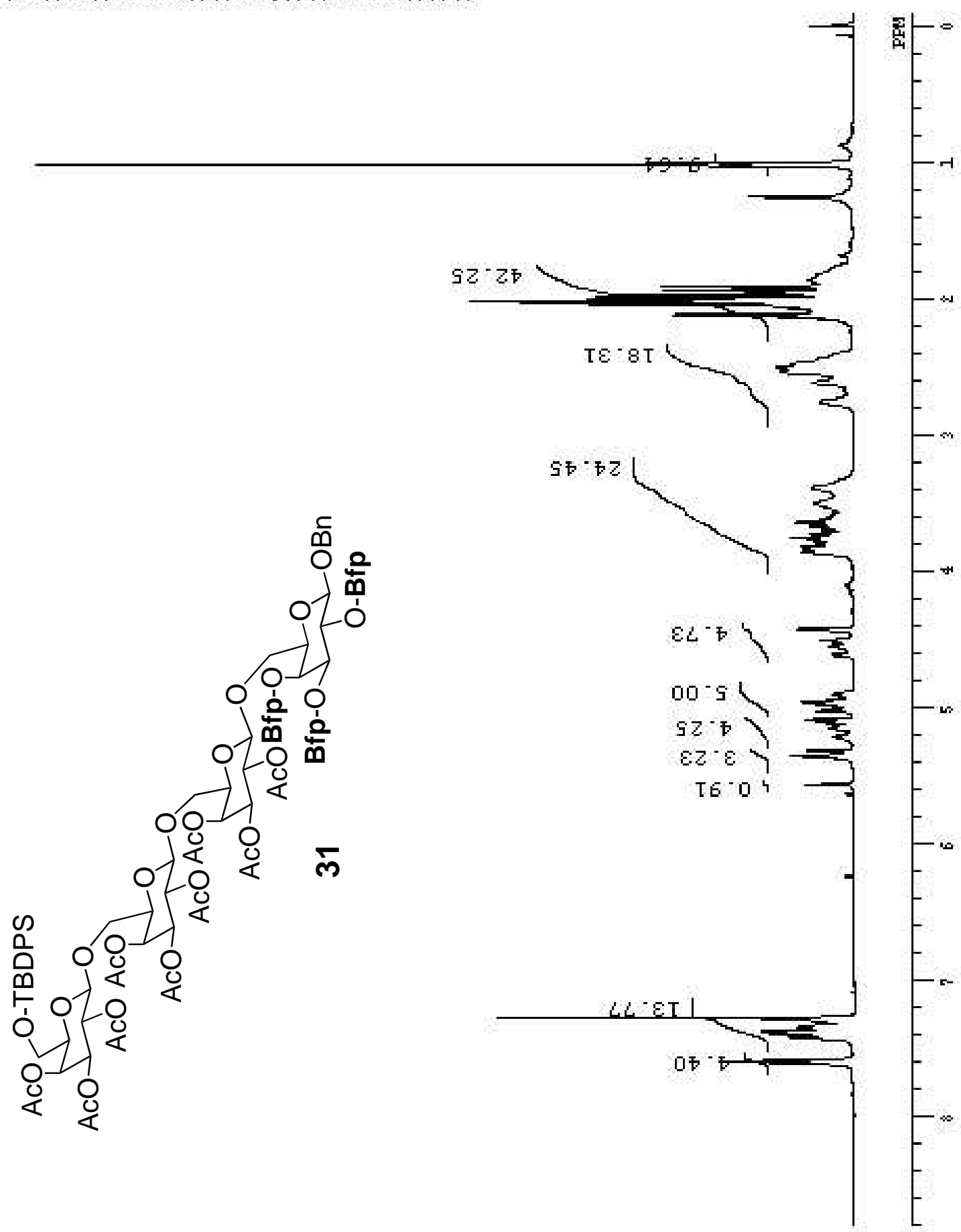


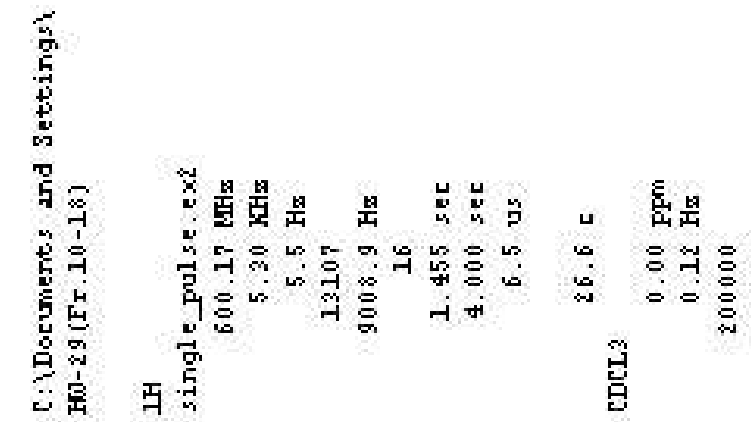

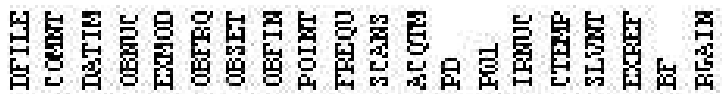

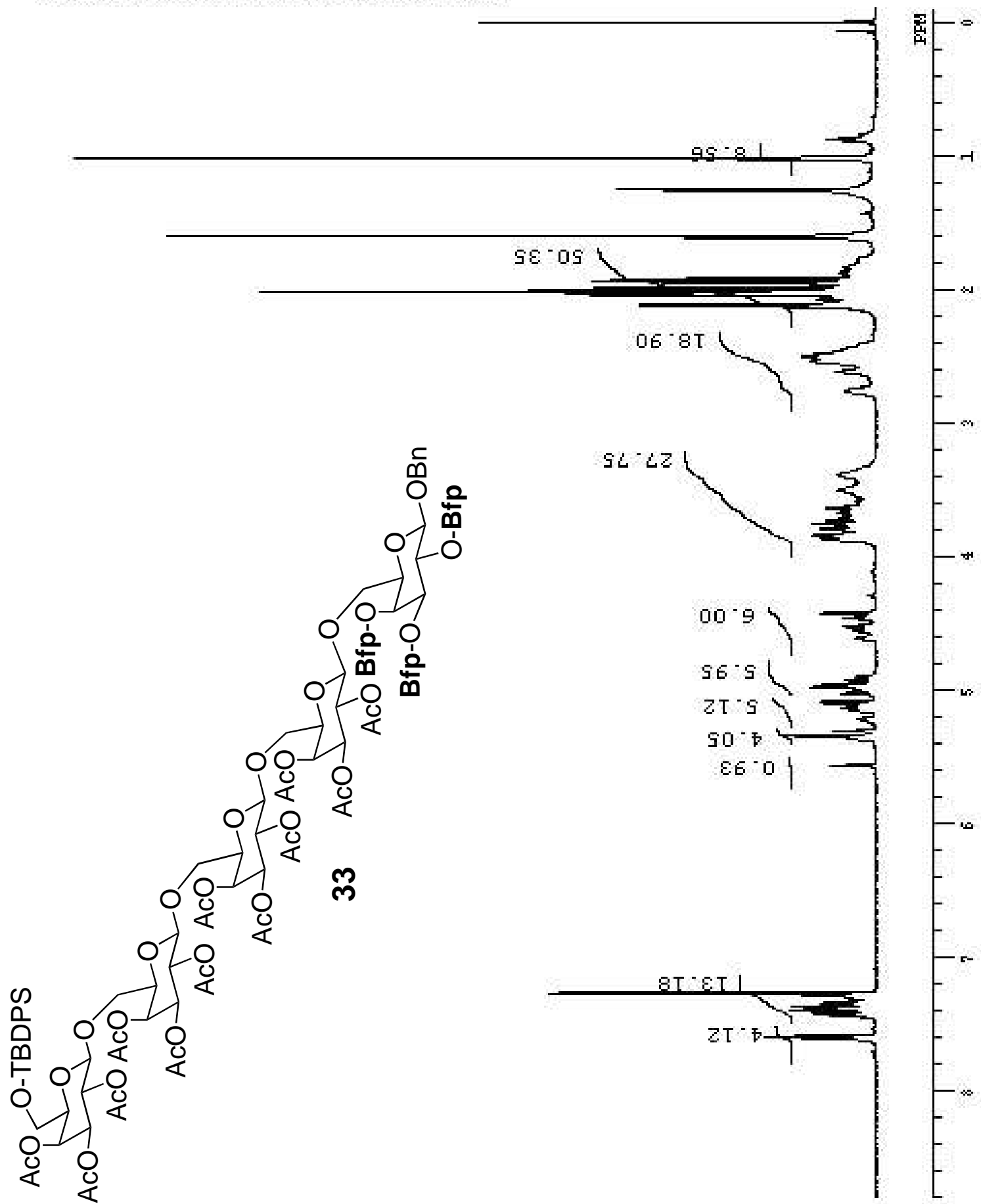




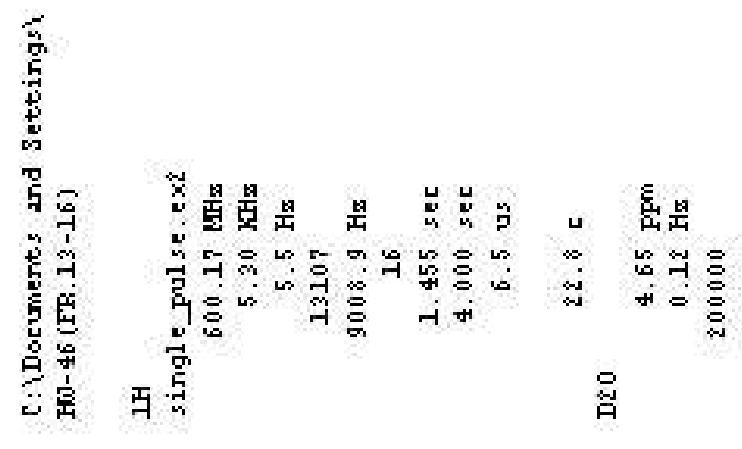

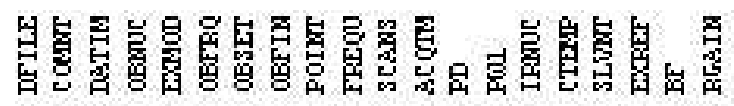
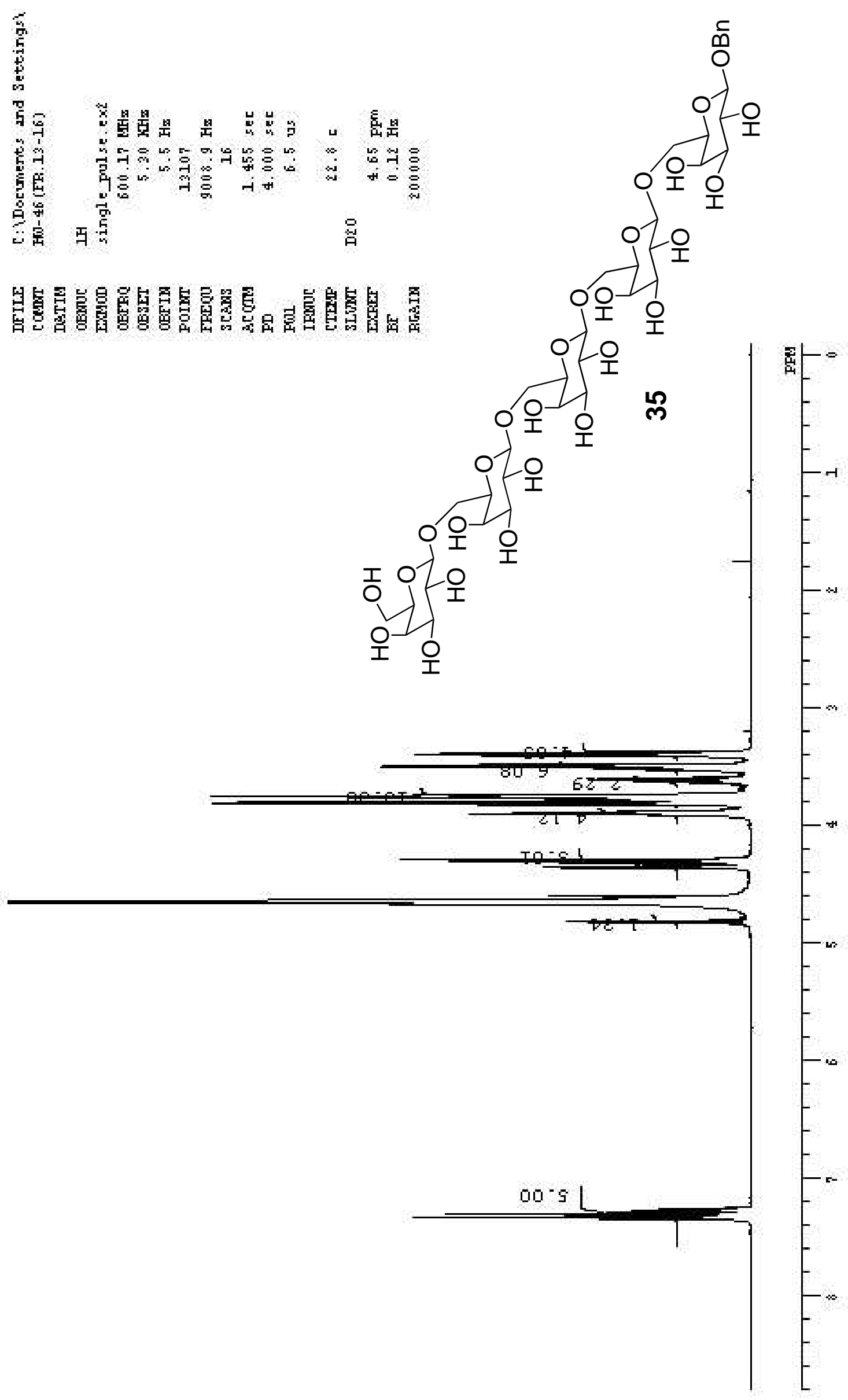


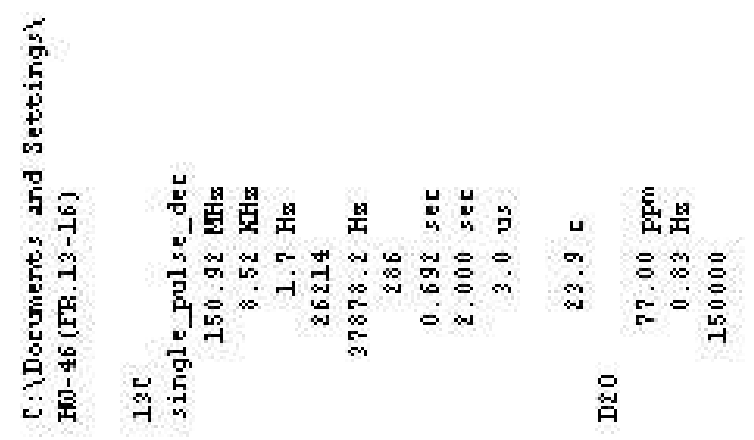

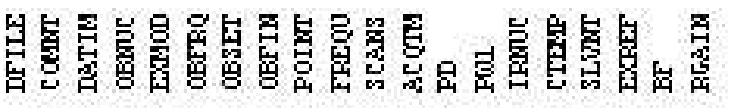
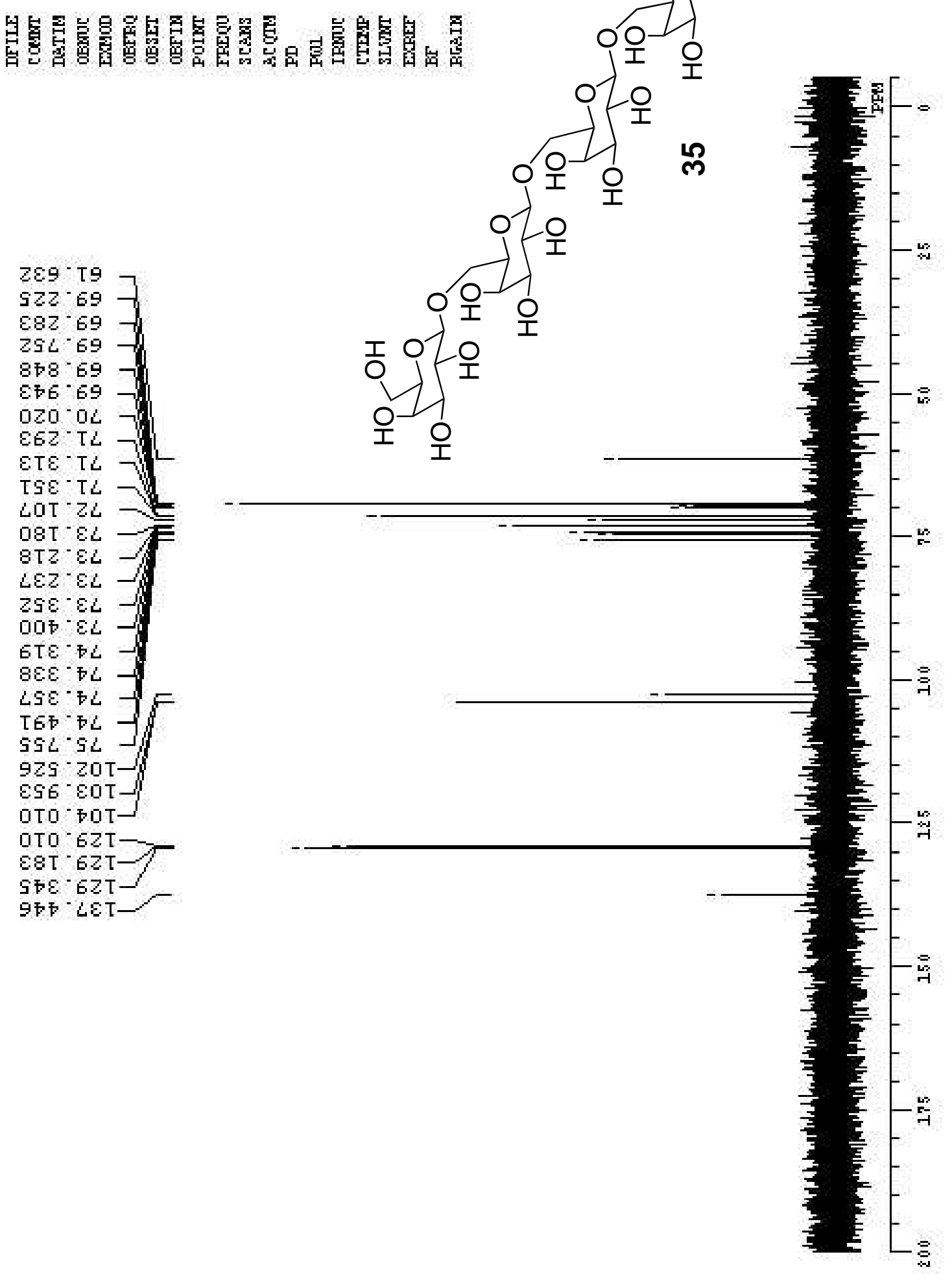


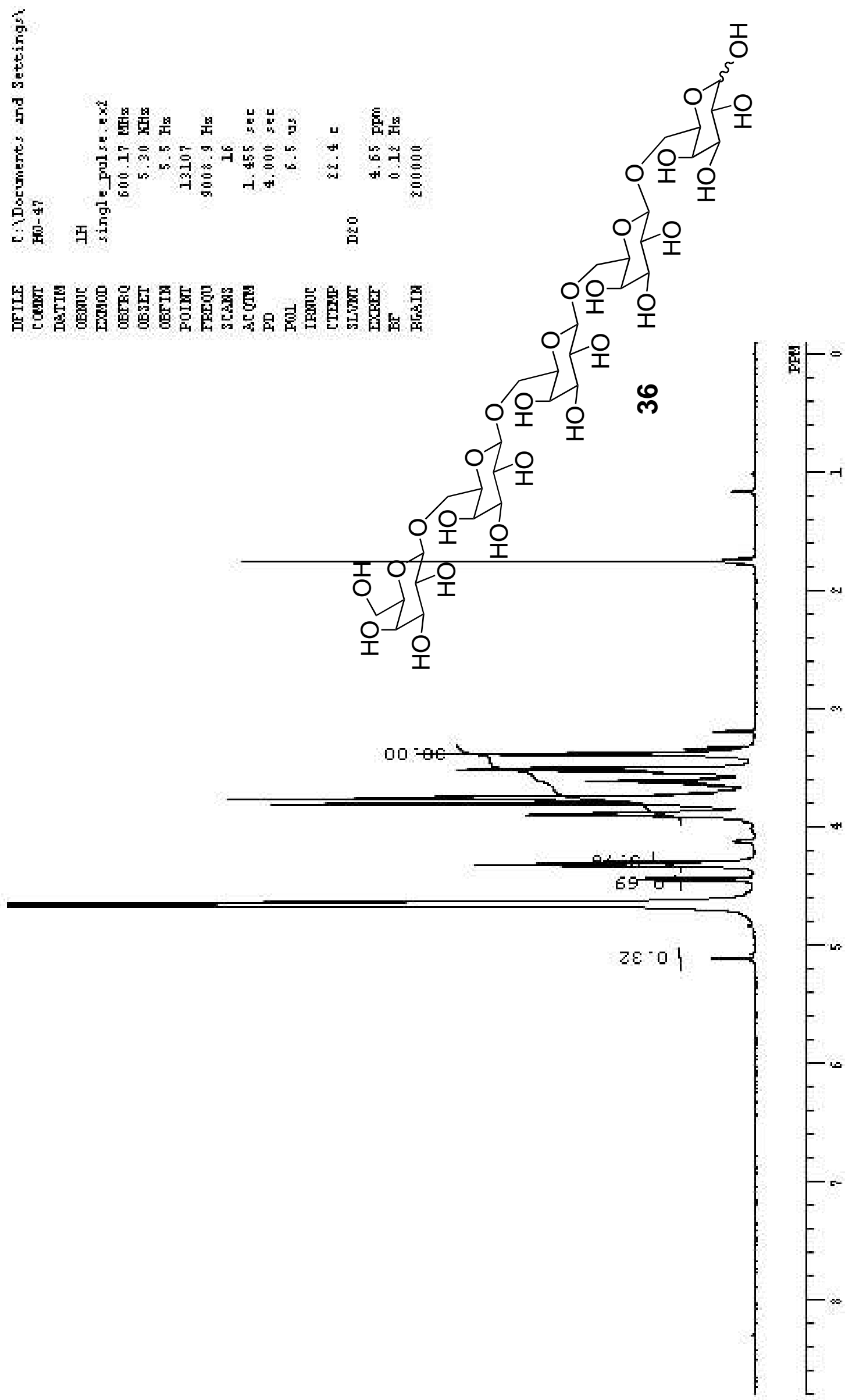




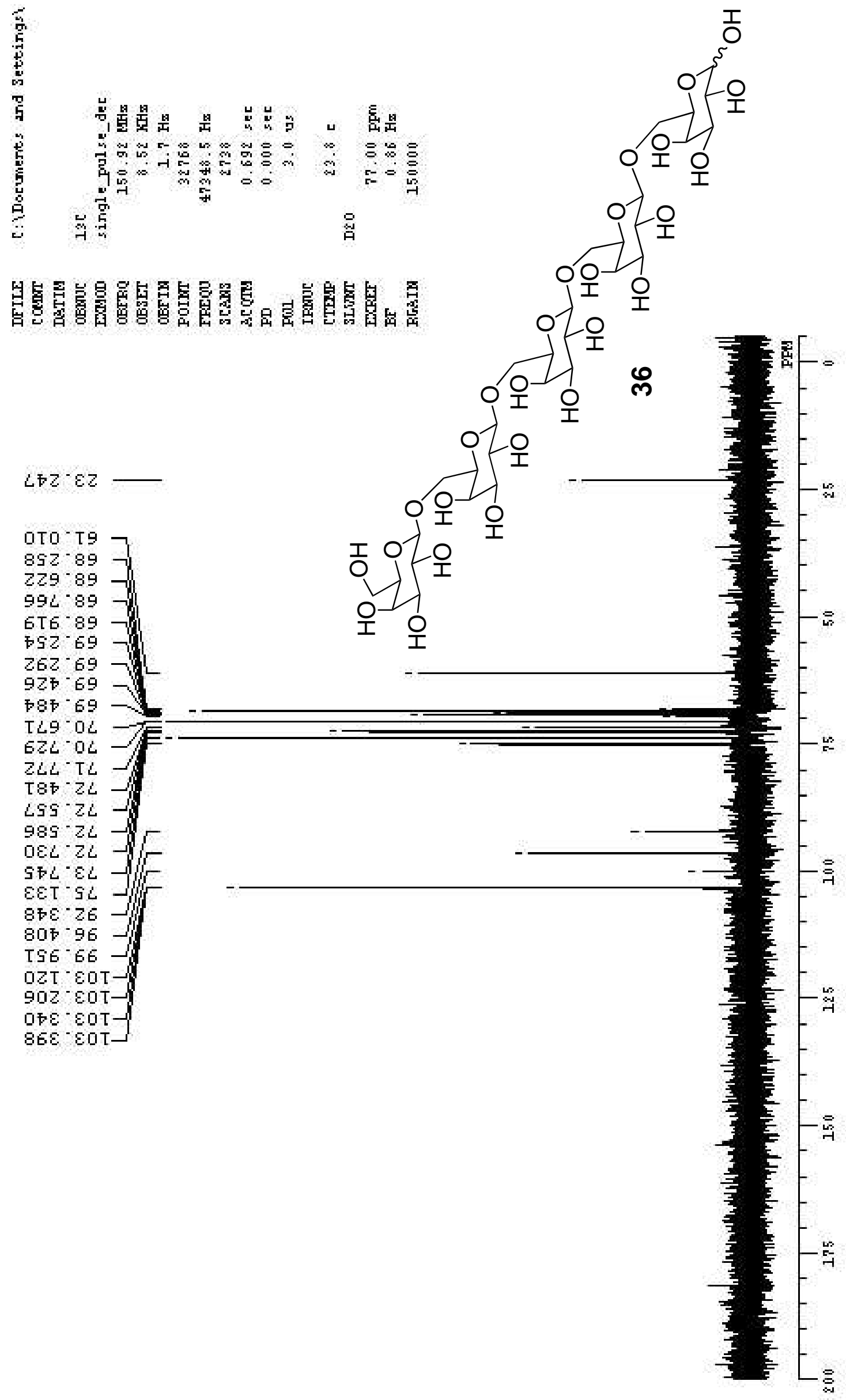

